\title{
Well Log Evaluation of \\ Natural Gas Hydrates
}

\author{
Topical Report
}

Timothy S. Collett

Work Performed Under Contract No.: DE-AI21-83MC20422

For

U.S. Department of Energy

Office of Fossil Energy

Morgantown Energy Technology Center

P.0. Box 880

Morgantown, West Virginia 26507-0880

By

Department of Interior

U.S. Geological Survey

P.O. Box 25046

Denver, Colorado 80225

October 1992 


\section{TABLE OF CONTENTS}

1. Introduction 1

2. Gas Hydrate Occurrences 6

A. Prudhoe Bay Gas Hydrate Occurrences 6

B. Walakpa Gas Hydrate Studies 12

C. DSDP Site 570 Gas Hydrate Occurrences 14

D. Cascadia Margin Gas Hydrate Studies 16

3. Gas Hydrate Well Log Interpretation 20

A. Well Log Responses $\quad 20$

B. Reservoir Porosity 25

C. Gas Hydrate Saturation 29

4. Conclusion 35

5. References Cited . 36 


\begin{abstract}
Gas hydrates are crystalline substances composed of water and gas, in which a solidwater-lattice accommodates gas molecules in a cage-like structure. Gas hydrates are globally widespread in permafrost regions and beneath the sea in sediment of outer continental margins. While methane, propane, and other gases can be included in the clathrate structure, methane hydrates appear to be the most common in nature. The amount of methane sequestered in gas hydrates is probably enormous, but estimates are speculative and range over three orders of magnitude from about 100,000 to $270,000,000$ trillion cubic feet. The amount of gas in the hydrate reservoirs of the world greatly exceeds the volume of known conventional gas reserves. Gas hydrates also represent a significant drilling and production hazard. Russian, Canadian, and American researchers have described numerous problems associated with gas hydrates, including blowouts and casing failures.

A fundamental question linking gas hydrate resource and hazard issues is: What is the volume of gas hydrates and included gas within a given gas hydrate occurrence? Most published gas hydrate resource estimates have, of necessity, been made by broad extrapolation of only general knowledge of local geologic conditions. Gas volumes that may be attributed to gas hydrates are dependent on a number of reservoir parameters, including the areal extent of the gas-hydrate occurrence, reservoir thickness, hydrate number, reservoir porosity, and the degree of gas-hydrate saturation. Two of the most difficult reservoir parameters to determine are porosity and degree of gas hydrate saturation. Well logs often serve as a source of porosity and hydrocarbon saturation data; however, well-log calculations within gas-hydrate-bearing intervals are subject to error. The primary reason for this difficulty is the lack of quantitative laboratory and field studies. The primary purpose of this paper is to review the response of well logs to the presence of gas hydrates. Also included in this paper is a description of the existing well-log evaluation techniques used to characterize porosities and water-saturations in gas-hydrate-bearing reservoirs.
\end{abstract}




\section{INTRODUCTION}

Gas hydrates (clathrate hydrates of natural gases) are naturally occurring solids composed of rigid cages of water molecules that entrap gas molecules. The water molecules are arranged in nearly spherical cage-like structures which contain, at most, one guest molecule bound by Van der Waals forces (reviewed by Sloan, 1990). While methane, propane, and other gases can be included in the clathrate structure, methane hydrates appear to be the most common in nature (Kvenvolden, 1988). Gas hydrates are characterized by two distinct structures known as Structure I and Structure II; both of these gas hydrates have the same basic structure, a pentagonal dodecahedron. Each unit cell of Structure I gas hydrate consists of 46 water molecules which form two small dodecahedral voids and 6 large tetradecahedral voids. Structure I gas hydrates can only hold small gas molecules such as methane and ethane, with molecular diameters not exceeding 5.2 angstroms. The composition of such a gas hydrate can be expressed as $8\left(\mathrm{Ar}, \mathrm{CH}_{4}\right.$, $\left.\mathrm{H}_{2} \mathrm{~S}, \mathrm{CO}_{2}, \mathrm{C}_{2} \mathrm{H}_{6}\right) 46 \mathrm{H}_{2} \mathrm{O}$ or $\left(\mathrm{Ar}, \mathrm{CH}_{4}, \mathrm{H}_{2} \mathrm{~S}, \mathrm{CO}_{2}, \mathrm{C}_{2} \mathrm{H}_{6}\right) 5.7 \mathrm{H}_{2} \mathrm{O}$ (Makogon, 1981). The unit cell of Structure II gas hydrate consists of 16 small and 8 large voids formed by 136 water molecules. Structure II gas hydrates may contain gases with molecular dimensions in the range of 5.9 to 6.9 angstroms, such as propane and isobutane. The composition of Structure II gas hydrates can be expressed by the formula $8\left(\mathrm{C}_{3} \mathrm{H}_{8}, \mathrm{C}_{4} \mathrm{H}_{10}, \mathrm{CH}_{2} \mathrm{Cl}_{2}\right.$, $\left.\mathrm{CHCl}_{3}\right) 136 \mathrm{H}_{2} \mathrm{O}$ or $\left(\mathrm{C}_{3} \mathrm{H}_{8}, \mathrm{C}_{4} \mathrm{H}_{10}, \mathrm{CH}_{2} \mathrm{Cl}_{2}, \mathrm{CHCl}_{3}\right) 17 \mathrm{H}_{2} \mathrm{O}$ (Makogon, 1981). At standard conditions (STP), one volume of saturated methane hydrate will contain as much as 164 volumes of methane gas (reviewed by Sloan, 1990); because of this large gas storage capacity, gas hydrates may represent an important source of natural gas.

Subsurface pressure and temperature conditions (figure 1) suitable for the occurrence of these solid gas deposits are globally widespread in permafrost regions and beneath the sea in sediments of outer continental margins (figure 2). Estimates of the amount of gas within the hydrates of the world are highly speculative and range over about three orders of magnitude, from $1.1 \times 10^{5}$ to $2.7 \times 10^{8}$ trillion cubic feet of gas (adapted from the 

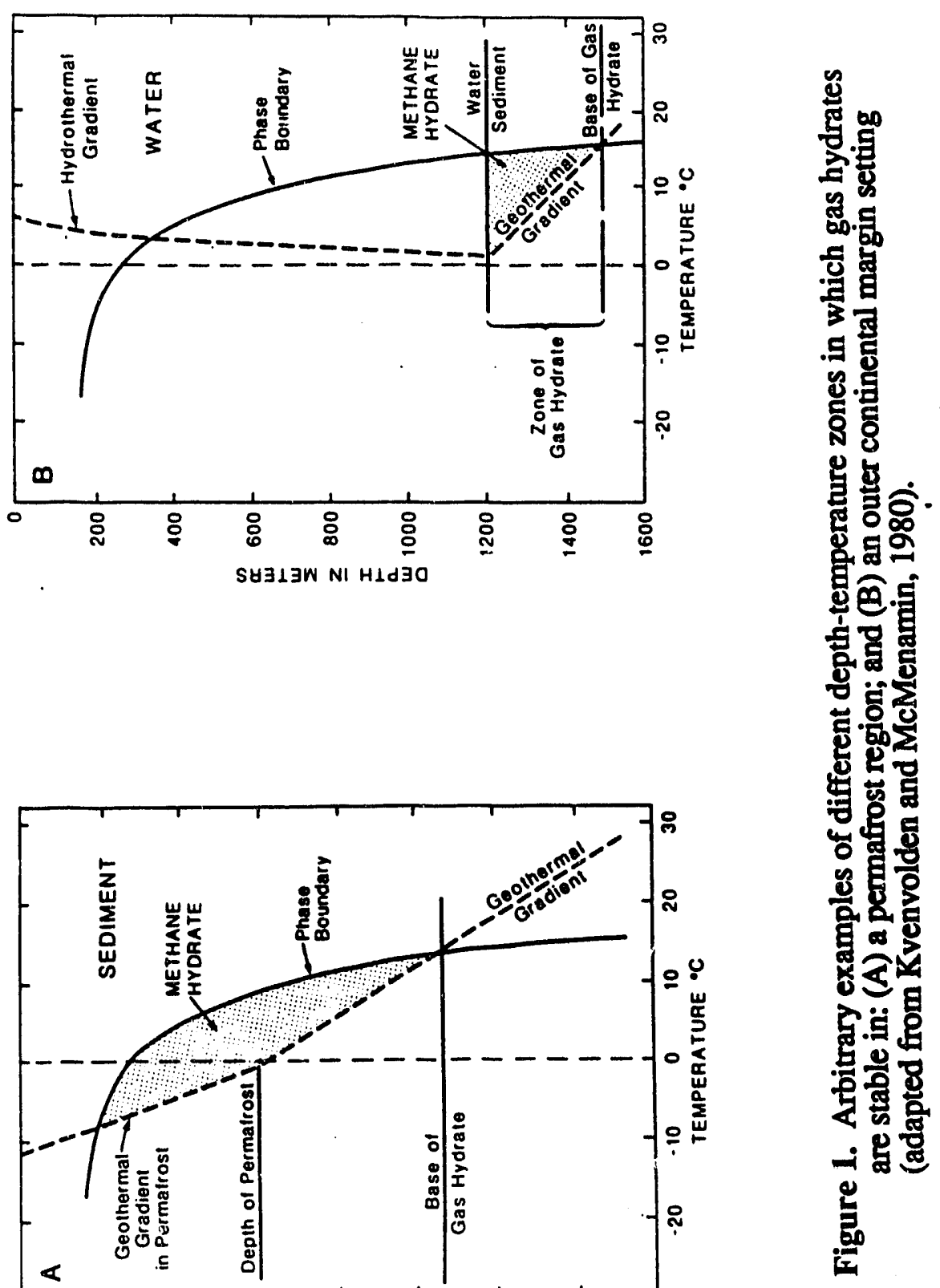


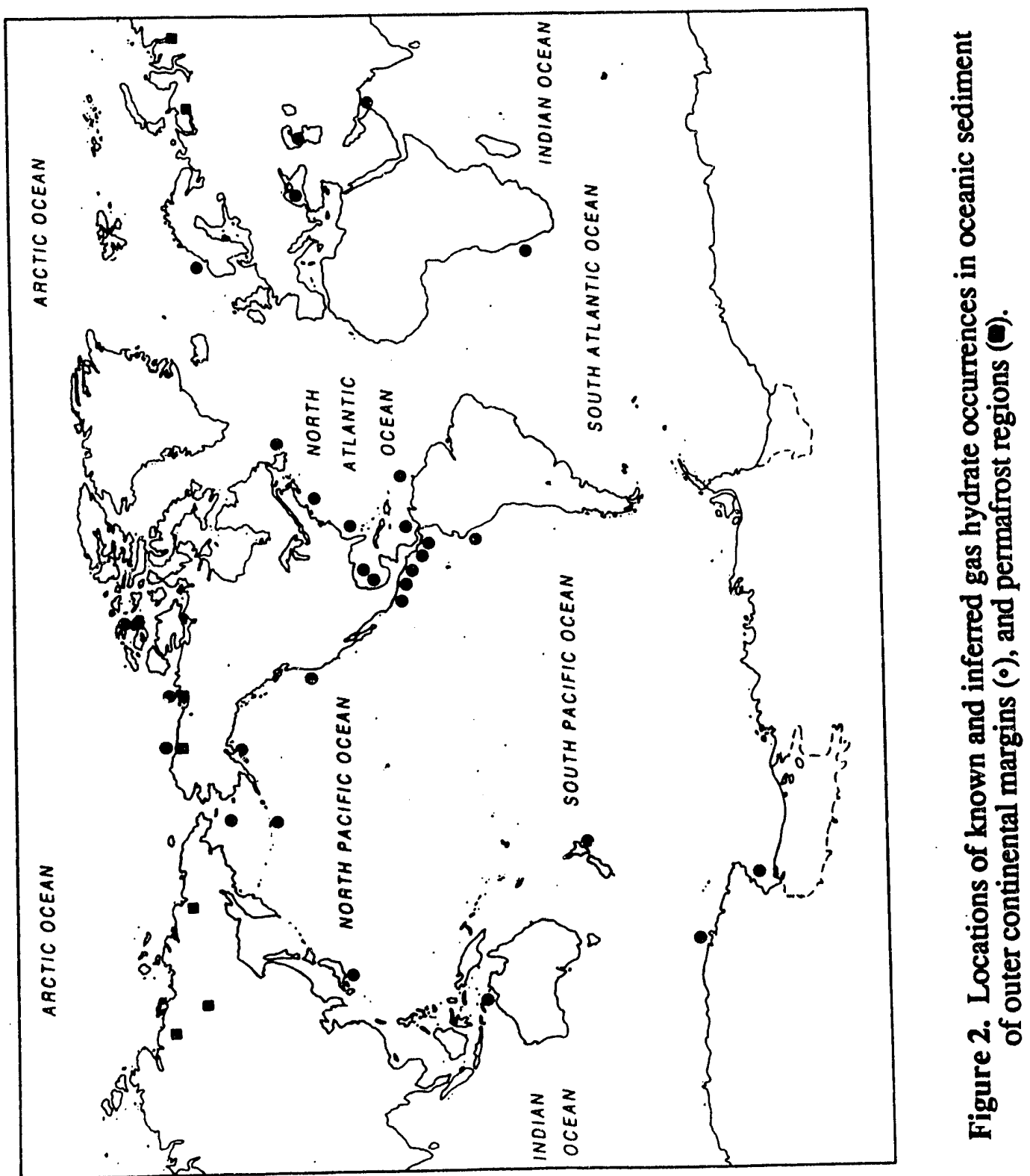


Potential Gas Committee, 1981). The amount of gas in the hydrate reservoirs of the world greatly exceeds the volume of known conventional gas reserves. Gas hydrates also represent a significant drilling and production hazard. Russian, Canadian, and American researchers have described numerous problems associated with gas hydrates, including blowouts and casing failures (Bily and Dick, 1974; Franklin, 1980; Makogon, 1981, Collett, 1990). As exploration and development activity moves into deeper water (>300 m) and high latitude arctic environments, the frequency of gas hydrate induced problems will likely increase.

The presence of gas hydrates in offshore continental margins has been inferred mainly from anomalous seismic reflectors that coincide with the predicted transition boundary at the base of the gas-hydrate stability zone (Kvenvolden and McMenamin, 1980). This reflector is commonly called a bottom-simulating reflector or BSR. BSR's have been mapped at depths below the sea floor ranging from $\approx 100$ to $\approx 1,100 \mathrm{~m}$. Gas hydrates have been recovered from near the sea floor in sediment of the Black Sea (Yefremova and Zhizhchenko, 1975) and the Gulf of Mexico (Brooks and others, 1986). Also, gas hydrates have been recovered at greater sub-bottom depths during research drilling and coring offshore southeastern USA (Kvenvolden and Barnard, 1983), Mexico (Shipley and Didyk, 1982), Guatemala (Harrison and Curiala, 1982; Kvenvolden and MacDonald, 1985), and offshore Peru (Kvenvolden and Kastner, 1989). Cold temperatures at high latitudes on Earth are conducive to the development of onshore permafrost and gas hydrate in the subsurface. Gas hydrates are known to be present in the western Siberian platform (Makogon and others, 1972) and are believed to occur in other permafrost areas of northern Russia, including the Timan-Pechora province, the eastern Siberian craton, and the northeastern Siberian and Kamchatka areas (Cherskiy and others, 1985). Permafrost-associated gas hydrates are also present in the North American Arctic. Well-log responses, attributed to the presence of gas hydrates, have been obtained in about a fifth of the wells drilled in the Mackenzie Delta; in the Arctic Islands over half of the wells 
are inferred to contain gas hydrates (Bily and Dick, 1974; Judge, 1988). Direct evidence for gas hydrates on the North Slope of Alaska comes from a core-test, and indirect evidence comes from drilling and open-hole well logs in the Prudhoe Bay and Kuparuk River oil fields (Collett, 1983; Collett and others, 1988; Collett and others, 1989). The combined information from Arctic gas-hydrate studies shows that in permafrost regions, gas hydrates may exist at subsurface depths ranging from $\approx 130$ to $\approx 2,000 \mathrm{~m}$. Gas hydrates may also be associated with permafrost in Antarctica, but few data are available (Hitchon, 1974; MacDonald, 1983); land-temperature profiles suggest that gas hydrates could exist to depths as great as $2,000 \mathrm{~m}$.

The primary objective of this paper is to review the existing well-log evaluation techniques used to study gas hydrates. To accomplish this objective I have included a description of the completed gas hydrate well log studies in northern Alaska and offshore Guatemala. Also included are discussions pertaining to drilling in the Walakpa gas field and the coring activities along the Washington-Vancouver coast. Gas hydrates have been inferred to occur at 38 locations throughout the world (Kvenvolden, 1988). However, only two of these occurrences have been sampled and surveyed with open-hole well logging devices. These two key well sites are the Northwest Eileen State-2 well on the North Slope of Alaska and the Deep Sea Drilling Project Site 570 borehole drilled in the Mid-America Trench off the Coast of Guatemala. Scheduled drilling in the Walakpa gas field in northern Alaska and research coring along the offshore Cascadia Margin from Vancouver to Oregon may add to this list of sampled and logged gas hydrate sites. This paper concludes with a review of expected gas hydrate well log responses and a description of existing well-log evaluation techniques used to characterize reservoir porosity and water saturations in gas-hydrate-bearing reservoirs. 


\section{GAS HYDRATE OCCURRENCES}

\section{A. Prudhoe Bay Gas Hydrate Occurrences}

The only confirmed natural gas hydrate occurrence on the North Slope of Alaska was obtained in 1972, when ARCO ALASKA and EXXON successfully recovered a core containing this substance (reviewed by Kvenvolden and McMenamin, 1980). This sample was from a depth of $\approx 666 \mathrm{~m}$ in the Northwest Eileen State-2 well, located within the Prudhoe Bay Oil Field (cored interval 664-667 m). The well was drilled with cool drilling muds in an attempt to reduce thawing of the permafrost and decomposition of the in-situ gas hydrates. The core containing the sample of gas hydrate was recovered in a pressurized core barrel. The presence of gas in a hydrated state was confirmed by a pressure test while the core was maintained in the core barrel at a temperature of about 1.0 ${ }^{\circ} \mathrm{C}$. As the gas was withdrawn from the core barrel, the pressure dropped, but it subsequently rose toward the theoretical gas-hydrate equilibrium pressure when the system was closed. If the core had contained only free-gas, the pressure in the barrel would have decreased linearly as gas was withdrawn and the pressure would not have increased when the system was closed. This gas hydrate pressure response was discussed by Hunt (1979, p. 167).

Recognition of gas hydrates with well logs in northern Alaska is not straight forward, and often the zones of potential hydrate occurrence are not logged, or the quality of the logs is poor. Another problem in the study of gas hydrates from well logs is the lack of prior quantitative work. The confirmed gas hydrate occurrence in the Northwest Eileen State-2 well is an ideal starting point for the development of gas hydrate well-log evaluation techniques. The responses of the commonly available well logs within the confirmed gashydrate interval of the Northwest Eileen State-2 well (figure 3) are summarized below.

1. Mud Log: On a mud log there is a pronounced gas kick associated with a gas hydrate due to hydrate decomposition during drilling. 


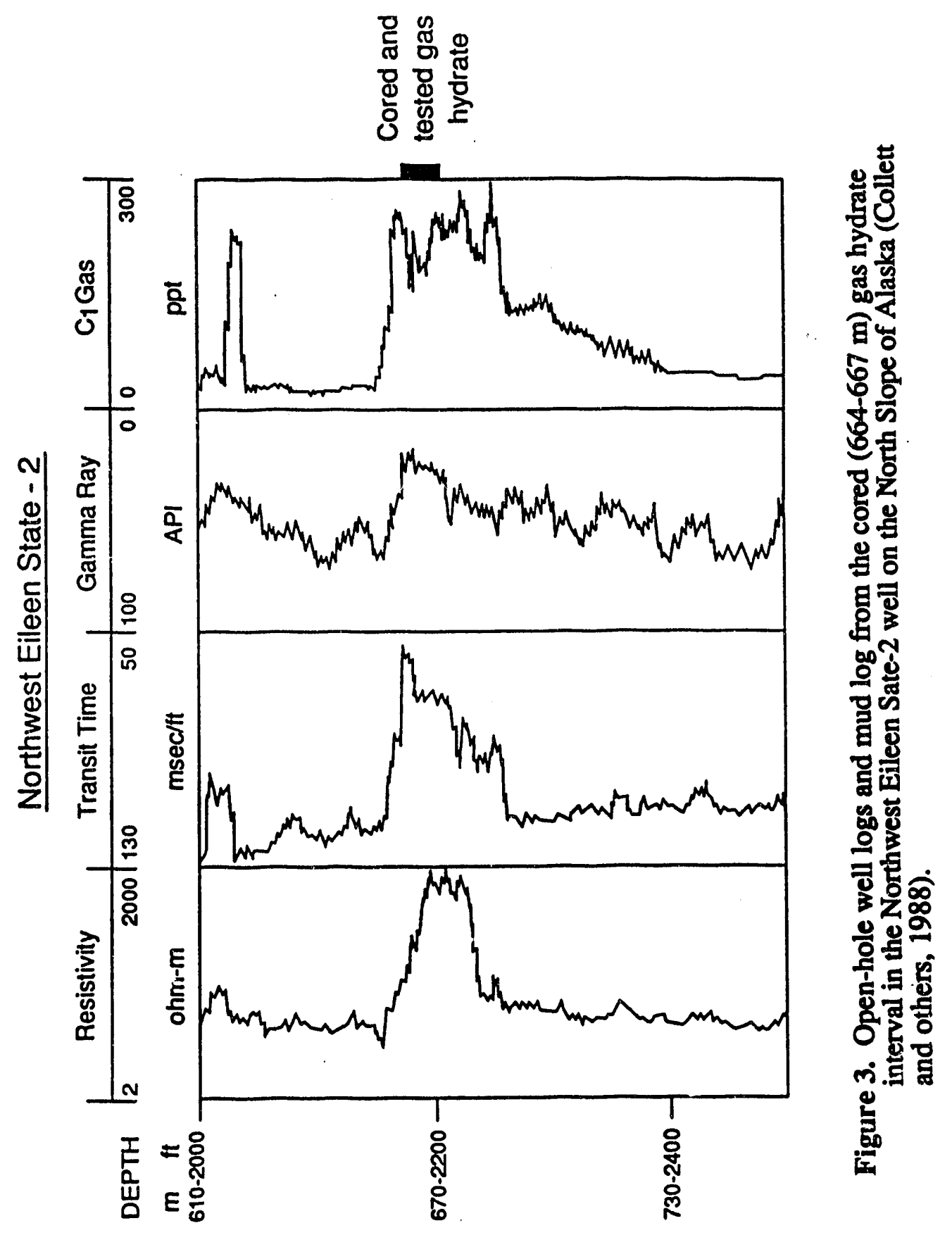


2. Dual Induction Log: There is a relatively high electrical-resistivity deflection in a gas-hydrate zone, in comparison to that in a free-gas saturated horizon. If a rock was gas-hydrate saturated within the ice-bearing permafrost sequence, the resistivity response on the induction log for the gas hydrate would not be significantly different from that in the surrounding ice-bearing permafrost. Below the base of the ice-bearing permafrost, however, the high-resistivity deflection associated with gas hydrate is distinct from the surrounding non-ice-bearing zones.

3. Spontaneous Potential (SP): There is a relatively lower (less negative) spontaneous-potential deflection in a gas-hydrate bearing zone when compared to that associated with a free-gas zone. The spontaneous-potential log-curve for a gas-hydrate would be similar to that of a ice-bearing sequence.

4. Caliper Log: The caliper log in a hydrate usually indicates an oversized well bore due to spalling associated with hydrate decomposition. The caliper also indicates an enlarged borehole within an ice-bearing sequence.

5. Acoustic Transit-Time Log: Within a gas hydrate there is a decrease in acoustic transit-time in comparison to a unit saturated with either water or free-gas. Because the acoustic transit-time of ice is similar to that of gas hydrate, the acoustic log cannot be used to identify gas hydrates within the ice-bearing permafrost sequence.

6. Neutron Porosity: In a gas hydrate there is an increase in the neutron porosity; this response contrasts with the apparent reduction in neutron porosity in a free-gas zone.

7. Density Log: Within a gas hydrate there is a decrease in density in comparison to a unit saturated with water. Because the density of ice is similar to that of 
gas hydrate, the density log cannot be used independently to identify a gas hydrate within ice-bearing permafrost.

8. Drilling Rate: In a gas hydrate the relative drilling rate decreases, due to the solid nature of the gas hydrate. There is a similar drilling rate response within icebearing horizons.

In most gas hydrate studies only dual-induction and acoustic transit-time logs are consistently used to identify potential gas hydrates. The dual-induction and acoustic logs behave similarly within a unit saturated either with gas hydrate or ice. Hence, the occurrence of gas shows on the mud log produced from decomposing hydrate often provides the only means of conclusively differentiating a gas hydrate from ice.

In northern Alaska, gas hydrates have been identified in 50 exploratory and production wells using well-log responses calibrated to the response of the cored gas hydrate interval in the Northwest Eileen State-2 well. Most of these well-log inferred gas hydrates occur in six laterally continuous Upper Cretaceous and lower Tertiary sandstone and conglomerate units; all these gas hydrates are geographically restricted to the area overlying the eastern part of the Kuparuk River Oil Field and the western part of the Prudhoe Bay Oil Field (figures 4 and 5). The volume of gas within these gas hydrates is estimated to be about $1.0 \times 10^{12}$ to $1.2 \times 10^{12}$ cubic meters ( 37 to 44 trillion cubic feet), or about twice the volume of conventional gas in the Prudhoe Bay Field. Geochemical analyses of well samples collected from nine industry wells suggest that the identified hydrates contain a mixture of deep-source thermogenic gas and shallow, microbial gas that was either directly converted to gas hydrate or first concentrated in existing traps and later converted to gas hydrate (Collett and others, 1989). The thermogenic gas probably migrated from deeper reservoirs along the same faults thought to be migration pathways for the large volumes of shallow, heavy oil that occur in this area (Carman and Hardwick, 1983). Recently completed three-dimensional seismic surveys have documented the 

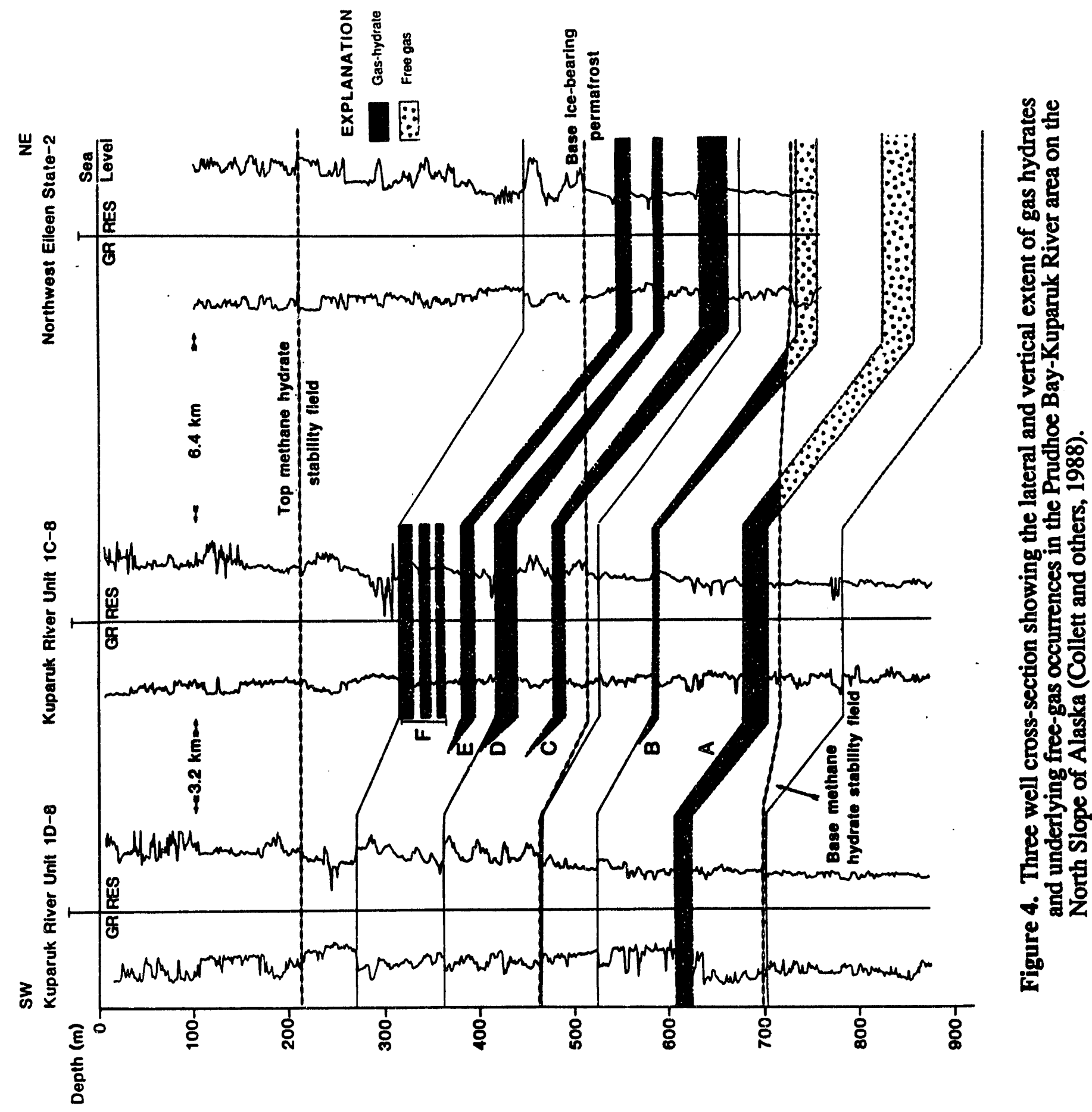


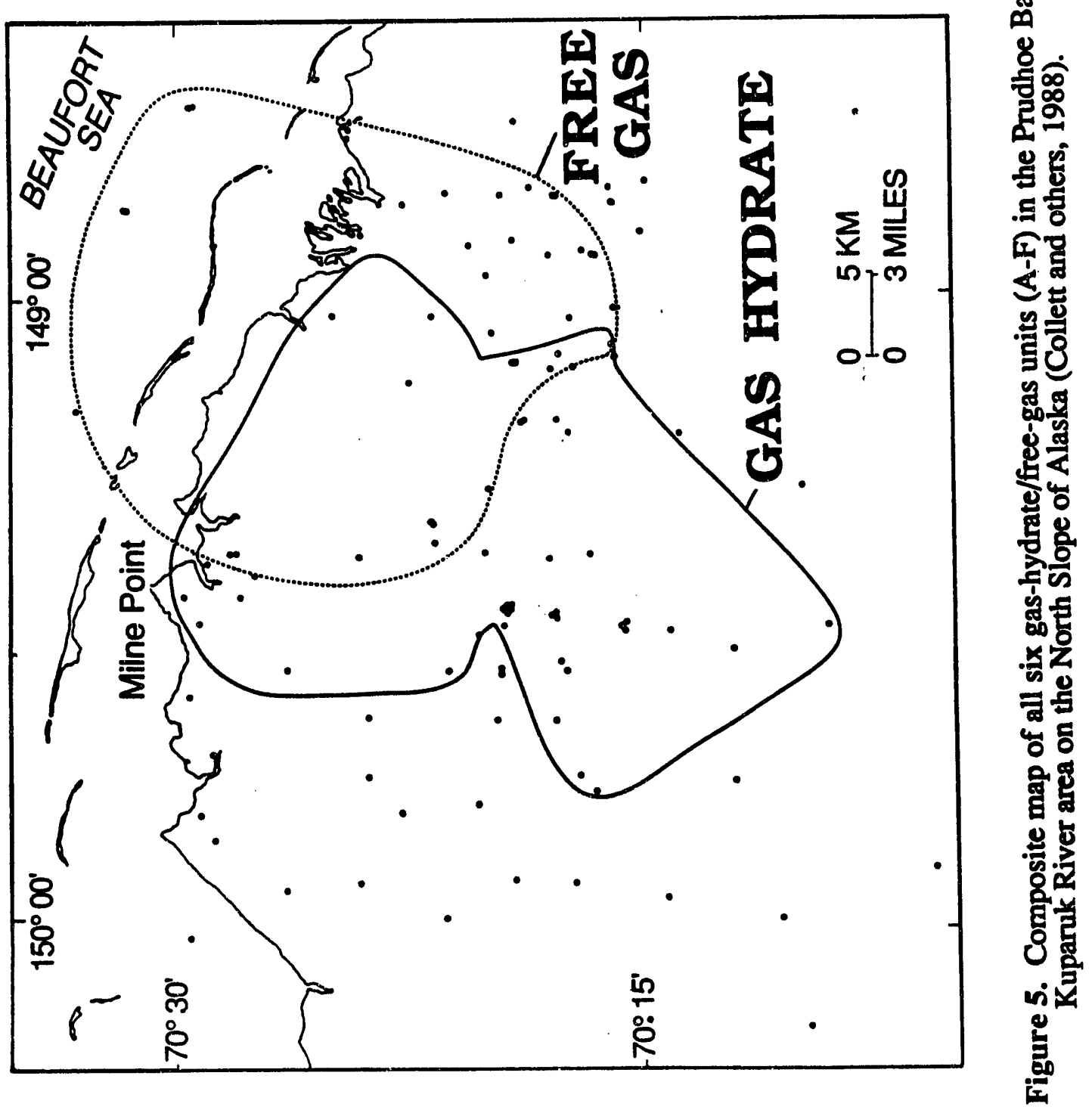


occurrence of a gas-hydrate/free-gas contact at the base of the methane-hydrate stability field in the west end of the Prudhoe Bay Oil Field (public presentation, C.G. Guderjahn, British Petroleum Exploration Inc., Anchorage, Alaska). Open-hole logs from wells in the west end of the Prudhoe Bay field also indicate the presence of a large free-gas accumulation trapped stratigraphically downdip below the log inferred gas hydrates. The presence of a gas-hydrate/free-gas contact within the Westend of the Prudhoe Bay production area is analogous to the Soviet Messoyakha gas-hydrate/free-gas accumulation in western Siberia; from which $\approx 183$ bcf of gas have been produced from the gas hydrates alone (Makogon, 1988). The geologic similarities between these two accumulations suggest that the gas hydrate depressurization production scheme utilized in the Messoyakha field may have direct application in northern Alaska. For more information on gas hydrate production methods see Yousif and others (1988), and Sloan (1990).

\section{B. Walakpa Gas Hydrate Studies}

In a recently completed development proposal for the Walakpa Gas Field (located $\approx 200$ miles northwest of Prudhoe Bay), the North Slope Borough reported that the up-dip extension of the Walakpa gas sands may lie within the zone of gas hydrate stability (figure 6). During the winter of 1990-1991, the North Slope Borough began preparations for the development of the Walakpa gas field. The development of this accumulation, discovered in the early 1980's by the U.S. National Petroleum Reserve in Alaska Exploration Program (Gryc, 1988), is designed to provide the city of Barrow with a long-term supply of natural gas. The Walakpa gas accumulation is situated in a broad, south facing domal structure and is overlain by permafrost. At its structurally highest point $(-1,500 \mathrm{ft}$ subsea) reservoir temperatures are at or near $0^{\circ} \mathrm{C}$. The Walakpa sandstone is generally described as a finegrained glauconitic sandstone, with poor to good porosity. The Walakpa sandstone is about 17 feet thick in the Walakpa-1 well and it thickens to about 35 feet in Walakpa-2. To the north of Walakpa-1 the reservoir thins and becomes siltier. The western extent is 


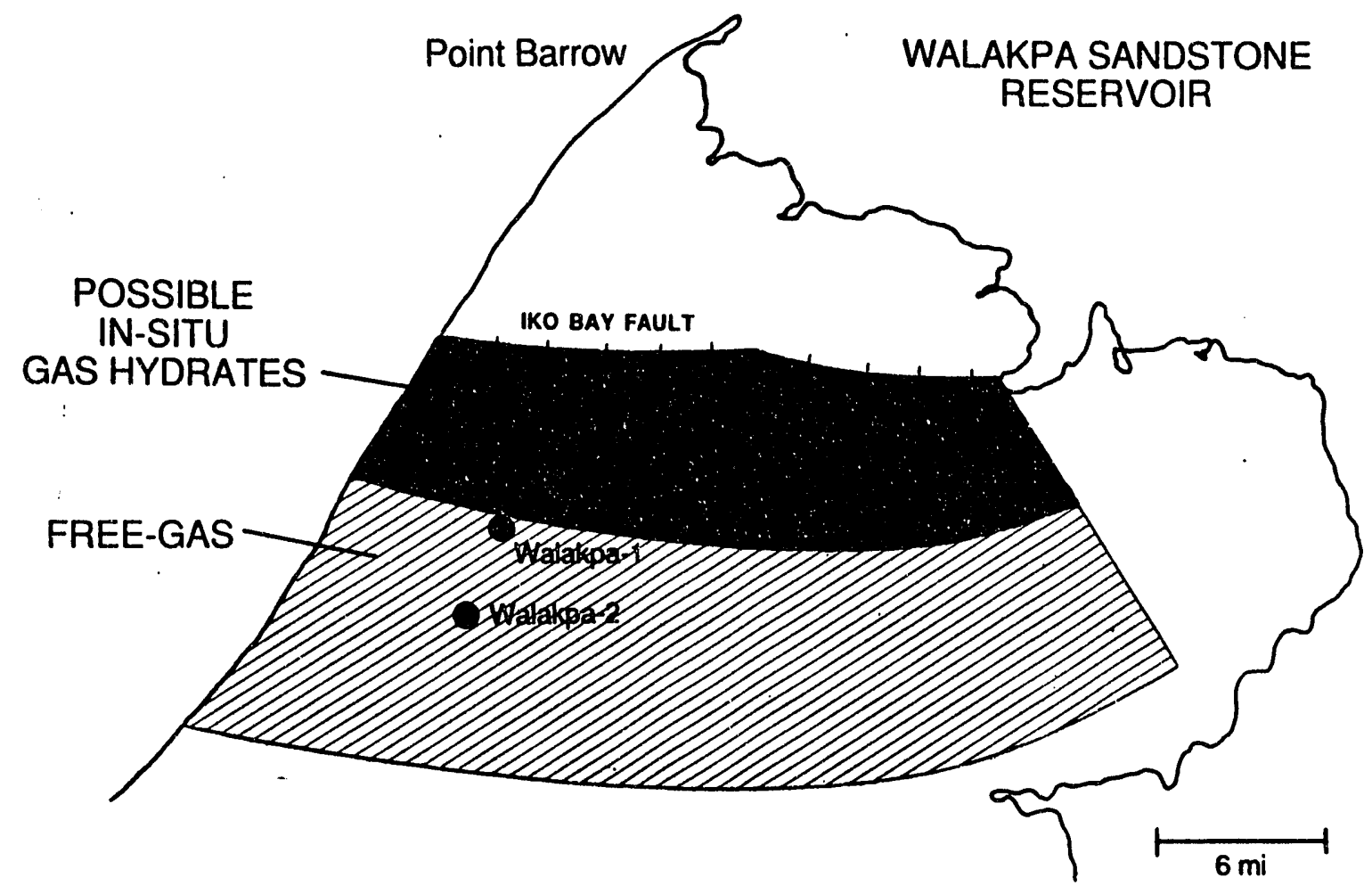

Figure 6. Potential distribution of the gas hydrate stability field in the Walakpa Gas Field on the North Slope of Alaska (Arctic Slope Consulting Group, 1990). 
unknown, but it appears to continue into the Chukchi Sea. A drill-stem test of the lower Cretaceous Walakpa sandstone in the Walaipa-2 well (confirmation well) recovered gas at the rate of 2.3 million $\mathrm{ft}^{3} /$ day. Thermal studies, suggest that the total areal distribution of the potential Walakpa gas hydrate accumulation may be more then 120 square miles (figure 6; Arctic Slope Consulting Group, 1990). The presence of gas hydrates would increase the reserves of the Walakpa gas field by several orders of magnitude. At this time, however, there is no direct evidence of gas hydrates in the Walakpa accumulation. Ongoing development drilling should provide the data necessary to assess the potential for gas hydrates in the Walakpa accumulation.

\section{C. DSDP Site 570 Gas Hydrate Occurrences}

In 1982, during coring operations on Leg 84 of the Deep Sea Drilling Project (DSDP) a $1.05 \mathrm{~m}$ long core of massive gas hydrate was recovered at Site 570 in the MidAmerica Trench off the Pacific coast of Guatemala. The cored gas hydrate sample was determined to be from the interval between 249.1 and $258.8 \mathrm{~m}$ sub-bottom depth. Well $\mathrm{log}$ surveys indicated that the actual thickness of the massive gas hydrate occurrence was about 3 to $4 \mathrm{~m}$ (Kvenvolden and MacDonald, 1985). Site 570 was drilled in 1,718 $\mathrm{m}$ of water and the well was completed at a sub-bottom depth of $402 \mathrm{~m}$ which is $300 \mathrm{~m}$ above the lower boundary of the gas hydrate stability field. Other cores from above and below the massive gas hydrate also showed evidence of gas hydrates. Summarized in table 1 are the shipboard scientists descriptions of the Site $\mathbf{5 7 0}$ gas hydrate occurrences (Kvenvolden and MacDonald, 1985).

Organic geochemical studies of carbon isotopic relations and compositions of natural gas mixtures, indicate that the methane in the gas hydrates of the Mid-America Trench is from biogenic sources (Kvenvolden and MacDonald, 1985). Inorganic geochemical studies of pore-waters in sediments associated with gas hydrates on Leg 84 showed that salinity and chloride content decreases with increasing depths (Kvenvolden 
GAS HYDRATES OF DSDP LEG 84 SITE 570

\begin{tabular}{ccl}
$\begin{array}{c}\text { Site \& } \\
\text { Core Number }\end{array}$ & $\begin{array}{c}\text { Subbottom } \\
\text { Depth }(\mathrm{m})\end{array}$ & \multicolumn{1}{c}{ Description } \\
\hline $570-21-1$ & 192 & Ash lamina with hydrate at top of core \\
$570-26-5$ & 246 & Hydrate in fractures of mudstone \\
$570-27-1$ & 249 & Massive hydrate, 1.05 m \\
$570-28$ & $259-268$ & Hydrate in fractures of mudstone \\
$570-29-3$ & 273 & Hydrate in fractures of mudstone \\
$570-32-4$ & 303 & Hydrate with volcanic ash \\
$570-36-1$ & 338 & Hydrate with sand lens \\
\hline
\end{tabular}

Table 1. Description of the gas hydrate occurrences in the DSDP Leg 84 Site 570 well (Kvenvolden and MacDonald, 1985). 
and MacDonald, 1985). Gas hydrates decompose during drilling, releasing fresh water and methane into the surrounding sediment, thus decreasing the salinity of the sediment pore-water.

A suite of ten well logs obtained at Site $\mathbf{5 7 0}$ define the massive gas hydrate interval (figure 7) (Mathews, 1986). The massive gas hydrate was characterized by high electrical resistivities $(\approx 155 \mathrm{ohm}-\mathrm{m})$, rapid acoustic transit-time velocities $(\approx 3.6 \mathrm{~km} / \mathrm{s})$, high neutron porosities $(\approx 67 \%)$, and low apparent densities $\left(\approx 1.05 \mathrm{~g} / \mathrm{cm}^{3}\right)$. The responses of the resistivity, acoustic transit-time, and density logs are most useful in identifying the in-situ gas hydrates (Mathews, 1986). Table 2 lists the log data from Site 570 and whether the data defines any of the gas hydrates encountered (modified from Mathews, 1986).

\section{D. Cascadia Margin Gas Hydrate Studies}

The Ocean Drilling Program Cascadia Margin Detailed Planining, Group (DPG) has recommended drilling a dedicated (700-m deep; sub-bottom depth) gas hydrate research well west of Vancouver Island. The proposed site of this research well is located in an area of continuous and well defined bottom simulating reflectors (BSR's). The major scientific objectives of this dedicated research well are to (1) calibrate the BSR response with the gas hydrate stability calculations, (2) test various gas hydrate formation models, (3) determine methane concentrations, and (4) characterize the gas hydrate well-log responses. After the well has been continuously cored and logged, it will be cased and a down-hole instrument package deployed to monitor temperatures and pore-fluid pressure conditions.

The standard suite of ODP logging tools will provide high resolution profiles of the physical properties (sonic velocity, porosity, electrical resistivity, and density) and lithology needed to assess the in-situ gas hydrate occurrences. The log data will also be used to calibrate geophysical observations which provide the regional framework necessary to describe the continental margin. In addition to the standard ODP logging package, the (DPG) planning group also recommended conducting vertical seismic profile (VSP) 


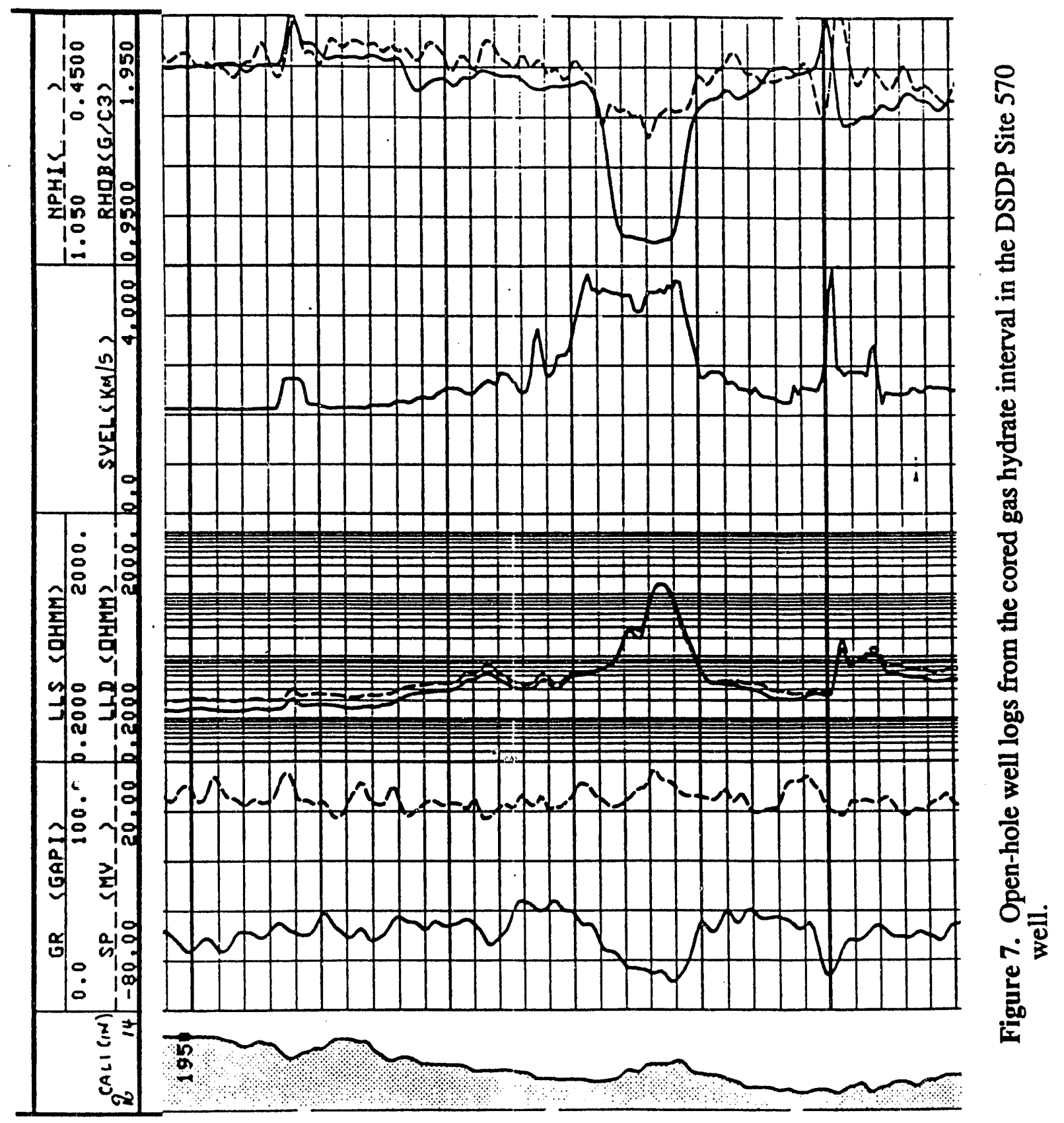




\section{DSDP SITE 570 WELL LOG DEFINED MASSIVE GAS HYDRATE}

Log Data

Massive Gas-Hydrate Zone

1,965.4-1,969.4 (m)

$\mathrm{P}$-wave sonic

Defines zone, $4 \mathrm{~m}$ thick

Density

Defines zone, $2.7 \mathrm{~m}$ thick

Resistivity

Both lls and lld define zone, $0.6 \mathrm{~m}$ deeper

Full-wave sonic

Wiggle trace marginally defines zone,

Variable density marginally defines zone

Gamma-ray

Defines zone, $0.5 \mathrm{~m}$ deeper

Neutron porosity

Defines zone, $0.5 \mathrm{~m}$ deeper

SP

Doesn't define zone

Caliper

Doesn't define zone

Temperature

Doesn't define zone

Table 2. Gas hydrate well log response in the DSDP Leg 84 Site 570 well (from Mathews, 1986). 
experiments and logging the hole with a Formation Microscanner (FMS). The planning group also recommended that the new digital Bore-Hole Televiewer (BHTV) should be used to $\log$ the more important intervals. 


\section{GAS HYDRATE WELL LOG INTERPRETATION}

Most published gas hydrate resource estimates have, of necessity, been made by broad extrapolation of only general knowledge of local geologic conditions (Potential Gas Committee, 1981; Collett and others, 1984; Mathews, 1986; Collett and others, 1988; Kvenvolden, 1988). A fundamental question linking the gas hydrate resource and hazard issues is: What is the volume of gas hydrates and included gas within a given gas hydrate occurrence? Gas. volumes that may be attributed to gas hydrates are dependent on a number of reservoir parameters, including the areal extent of the gas-hydrate occurrence, reservoir thickness, hydrate number, reservoir porosity, and the degree of gas-hydrate saturation (Collett and others, 1988). Two of the most difficult reservoir parameters to determine are porosity and the degree of gas hydrate saturation. Well logs often serve as a source of porosity and hydrocarbon saturation data; however, well-log calculations within gashydrate-bearing intervals are subject to error. The primary reason for this difficulty is the lack of quantitative laboratory and field studies.

In the next section of this report I have reviewed the well log responses of the devices that are thought to be effected by the presence of gas hydrates. This section concludes with a description of existing well-log evaluation techniques used to characterize porosity and water saturations in gas-hydrate-bearing reservoirs.

\section{A. Well Log Responses}

Numerous well logging devices appear to respond to the presence of gas hydrates. In most cases these responses are poorly understood or are only theorized to occur. The well logs considered include electrical resistivity, dielectric, acoustic transit-time, gammagamma density, neutron, and nuclear magnetic resonance devices.

The electrical resistivity of most rock intervals are controlled by the pore fluids. The relation between rock and pore fluid resistivity has been studied in numerous laboratory experiments. From these studies, reliable relations among, porosity, pore fluid 
resistivity, and rock resistivity have been found, but the theoretical basis for these empirical findings is incompletly understood. Among these finuings are the two empirical relations established by Archie (Schlumberger Educational Services, 1989) which cre used to estimate water saturations in a gas/oil/water system. In comparison, gas hydrate and gas/oil-bearing reservoirs appear to be characterized by relatively similar resistivities, which suggest that the Archie relations may be used to caiculate gas hydrate saturations.

However, no attempt has yet been made to test the usefulness of the Archie relations in gashydrate-bearing reservoirs.

Resistivity tools operate at low to medium frequencies $(0$ to $20,000 \mathrm{~Hz})$; thus, the dielectric properties of rock can be ignored. At high frequencies (20 to 1,100 MHz), however, dielectric properties begin to dominate the propagation of electromagnetic waves. Dielectric sondes make use of the electromagnetism theory to measure phase shift and attenuation of a propagating wave over an known distance, which is controlled by the dielectric constant of the medium. Since the dielectric constant of gas and oil, in comparison to water, differ by as much as 78 farads/meter, the log derived propagation times can be used to calculate saturations in a oil/gas/water system. However, since the dielectric constant of Structure I gas hydrate ( $\approx 58$ farads/meter) is near the dielectric constant for water (59 to 79 farads/meter) it is unlikely that the dielectric logs would yield accurate saturations in a gas-hydrate-bearing reservoir.

Acoustic transit-time logs are based on the propagation of elastic vibrations through a medium. There are two main types of elastic waves; compressional and shear. The attenuation of compressional and shear sound waves in rocks depend on many properties of the rock, including density, porosity, saturations, and the amount of fracturing. The velocity of a shear wave in a solid medium is about half that of compressional waves, and shear waves do not exist in liquids or gases. In most conventional acoustic well log studies, the log derived transit-times are used to calculate rock porosities. The Wyllie timeaverage formula relates the velocity of the bulk material to the velocity of the rock matrix 
and fluid to determine porosity. Unlike gas or water, gas hydrates support shear waves. Whally (1980) and Whiffen and others (1982) calculated the velocity of a compressional wave in a gas hydrate (I) to be $3.8 \mathrm{~km} / \mathrm{sec}$. Pandit and King (1983) determined the velocity of shear waves in gas hydrate (I) to be $\approx 1.9 \mathrm{~km} / \mathrm{sec}$. Thus, the apparent rapid transit-times observed on acoustic well logs in gas hydrates (relative to gas or water) can be attributed to both high compressional and shear wave velocities. It is often possible to recognize shear and compressional arrivals on variable-intensity displays (full-wave acoustic). This ability to obtain shear wave velocities could prove to be valuable in gas hydrate research. However, no gas hydrate acoustic well log characterization studies have been conducted.

The basic design of a gamma-gamma density sonde consists of a gamma-ray source and detectors placed some distance apart. The emitted gamma-rays are scattered within the formation and some of these scattered gamma-rays return to the detector. The attenuation of the log emitted gamma-rays is controlled by the bulk density of the formation. Porosities calculated from density logs in a hydrocarbon-bearing reservoirs are subject to error since most density devices are calibrated to the density of the drilling fluids. However, if the density of the hydrocarbon is known it is possible to correct the density derived porosities. In theory, it should also be possible to correct the density derived porosities for the presence of gas hydrates. However, there is no experimental evidence to support this assumption.

Neutron devices emit fast neutrons from either radioactive sources or particle accelerators. As the fast neutrons collide with the nuclei of atoms in the rock medium the neutrons thermalize or slow. The slowed neutrons are eventually captured by atoms and gamma-rays of capture are emitted. The neutron logs can be grouped into three categories: (1) logs that measure the number of slowed neutrons, (2) logs that analyze the rate at which the neutrons slow, and (3) logs that analyze the gamma-rays emitted from the interactions between the sourced neutrons and atomic nuclei. The slowing of fast neutrons emitted by the logging tool is caused by collisions with hydrogen nuclei, whose mass is almost 
identical to that of a neutron. Thus, neutron logs that measure the number of slowed neutronis or analyze the rate at which neutrons slow are actually measuring the amount of hydrogen within the pore-space of the rock sequence. The amount of hydrogen in a rock sequence is related to the amount of water and hydrocarbons, including gas hydrates, that are present. Through the aid of stoichiometric chemistry, it is possible to calculate the amount of hydrogen present in a cubic unit of pore volume for the following constituents: water, methane, ice, structure I gas hydrate, structure II gas hydrate (table 3; adapted from Collett and others, 1984). An increase in the hydrogen content would relate to an increase in the number of slowed neutrons and the rate at which the neutrons slowed would be greater. Thus, assuming constant porosity, a rock saturated with a structure II gas hydrate would more effectively slow (thermalize) the log emitted neutrons then a rock saturated with only water or methane (table 3 ). This relation suggests that with aid of stoichiometric chemistry and computer log response modeling it should be possible to develop neutron logging evaluation techniques that would yield accurate reservoir porosity and saturation data from gas-hydrate-bearing rock sequences:

Although neutron logs measure total hydrogen content, nuclear magnetic resonance logs can measure the amount of hydrogen free to move. Under the influence of a magnetic field, hydrogen nuclei, found in water as well as hydrocarbons, will tend to align in the direction of the field. The time required for this alignment is referred to as longitudinal relaxation time $\left(T_{1}\right)$. If the applied field is suddenly switched off the hydrogen nuclei will precess about the direction of the earth's magnetic field as it returns to a disordered state. The rate at which the hydrogen nuclei returns to a disordered state, referred to as the relaxation time of transverse magnetization $\left(T_{2}\right)$, depends on the thermal relaxation characteristics of the hydrogen-bearing substances. For example, the transverse magnetization relaxation time $\left(\mathrm{T}_{2}\right)$ for hydrogen nuclei in solids is very short; the relaxation time $\left(\mathrm{T}_{2}\right)$ for hydrogen nuclei in fluids, however, can vary from tens to hundreds of 


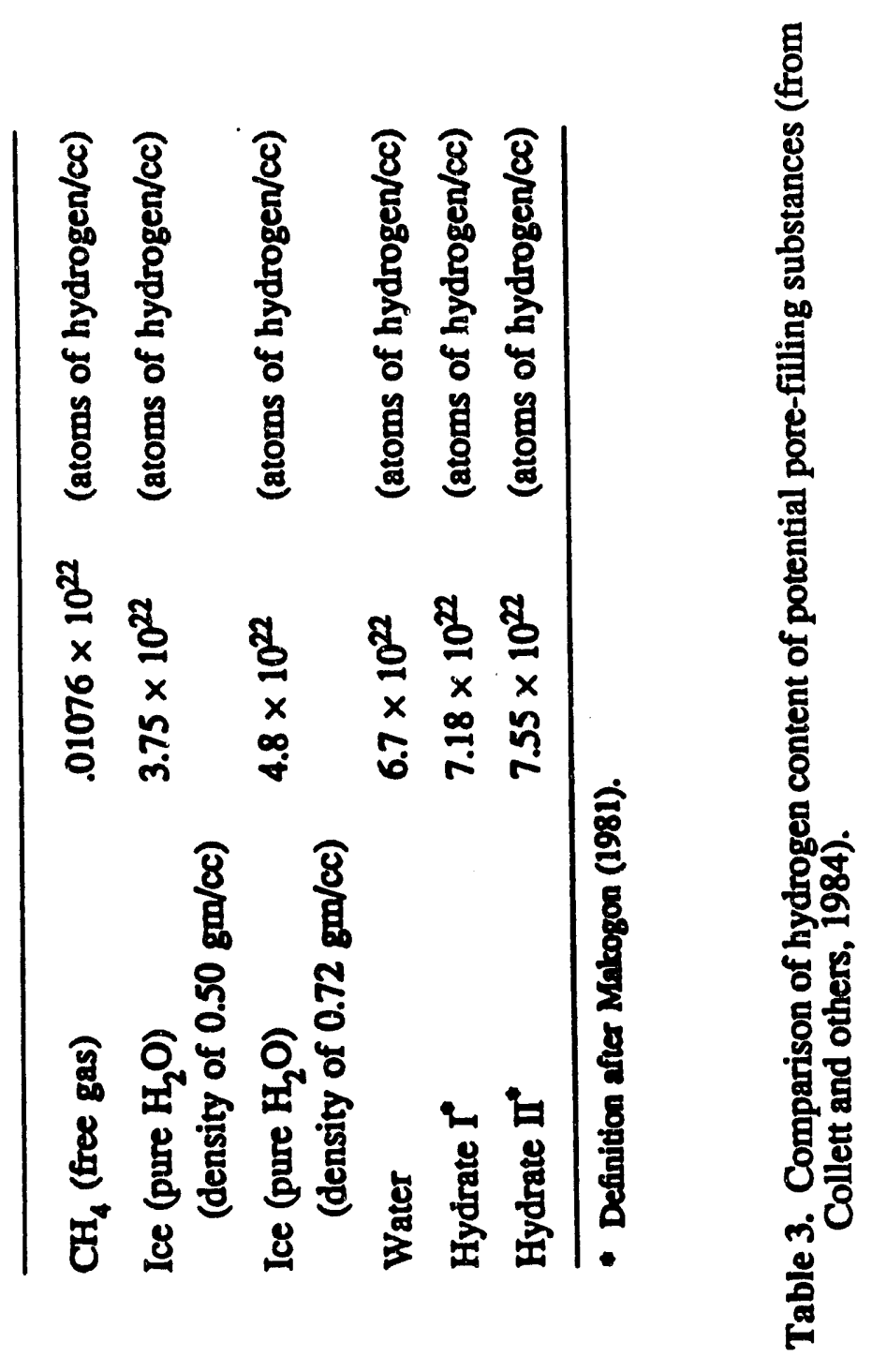


milliseconds, depending on the fluid's viscosity and its interactions with nearby surfaces (Hearst and Nelson, 1985).

Several nuclear magnetic resonance laboratory experiments have provided evidence about the motion of the water molecules in the crystal structure of gas hydrates (reviewed by Davidson and Ripmeester, 1984). At temperatures greater than 200-250 K, the motion of the water molectles in gas hydrate becomes appreciable and nuclear magnetic resonance analysis suggest that the first order contribution to motion is due to reorientation of water molecules in the gas hydrate structure. Laboratory measurements suggest that the longitudinal relaxation time $\left(T_{1}\right)$ for the water molecules in the gas hydrate structure is relatively rapid in comparison to water molecules in others solids. Thus a nuclear magnetic resonance well log may be responsive to gas hydrates.

\section{B. Reservoir Porosity}

The neutron-porosity log measures the attenuation in the passage of neutrons emitted by the logging tool into the rock sequence. This response is a measure of the hydrogen content of the formation. As previously discussed, it is possible to calculate the amount of hydrogen present in a given pore volume of the following constituents: water, pure methane, ice, Structure I and Structure II gas hydrates (table 3). The neutron-porosity $\log$ response to increasing hydrogen content is an apparent increase in neutron-porosity. Conversely a decrease in hydrogen content results in an apparent reduction in the recorded neutron-porosity. From this relation, and by utilizing the calculated hydrogen volumes in table 3 , it is possible to formulate the following relation: assuming constant porosity, a rock saturated with a Structure II gas hydrate would more effectively slow the log emitted neutron then a rock saturated with only water or methane. Thus, a Structure II gas hydrate would be characterized by relatively high apparent neutron-porosities, and a free-gas saturated unit would exhibit low apparent porosities. By making several assumptions about borehole conditions and taking into account the hydrogen pore-volume content for 
the different constituents listed in table 3 , it is possible to correct the neutron porosity data within a gas-hydrate-bearing interval. Standard neutron-porosity well-log evaluation procedures assume that the pore-volume of a rock unit is occupied by only water. However, if a hydrocarbon such as free-methane gas is present within the rock unit, the log-derived neutron-porosities require correction. These corrections are often accomplished by using empirically derived correction factors. With the aid of stoichiometric chemistry it should be possible to develop a neutron-porosity correction factor for a gas-hydrate-bearing unit. By assuming constant porosity between two units, one saturated with Structure I gas hydrate and the second with water, it is possible to determine the following ratio:

Amount of hydrogen in $1 \mathrm{cc}$ of water

Amount of hydrogen in 1cc of gas hydrate (1)

$$
\frac{6.7 \times 10^{22} \text { (atoms of hydrogen/cc) }}{7.18 \times 10^{22} \text { (atoms of hydrogen/cc) }}=0.93
$$

This ratio can be used as a neutron-porosity log correction factor within a gas-hydrate saturated reservoir in order to obtain accurate porosities.

The standard neutron log has a number of limitations, including sensitivity to borehole conditions. Enlargement of the borehole due to decomposing gas hydrates or thawing ice affects the recorded neutron-porosity data. The maximum sensing depth of the compensated neutron device ranges from 5 to $15 \mathrm{~cm}$. Drilling procedures employed on the North Slope of Alaska, may cause a gas hydrate to decompose to a depth of 3 to $6 \mathrm{~cm}$ into the formation from the borehole (Collett and others, 1988). The vacated pore-space within the decomposed zone can be occupied by a wide array of constituents, including drilling fluids and free-gas from gas-hydrate dissociation, which directly affect the neutron log response. Unrecognized changes in lithology may also cause erroneous interpretations. 
The acoustic log measures the time required for a sonic wave to travel through the formation adjacent to the wellbore. Acoustic travel-time can be related to porosity when lithology and pore-fluid properties are known. Compressional and shear wave velocities of a formation are not only properties of the matrix and pore fluid velocities but are also affected by the temperature of the formation and the salinity of the pore-fluids (Pandit and King, 1979). In standard formation evaluation procedures, the empirical Wyllie equation is used to relate travel time and porosity. The Wyllie equation does not account for the effect of free-gas on the acoustic device, but, an empirical correction factor for the free-gas effect has been calculated. It has been suggested that the effect of gas hydrate on the velocity device can be determined, and an empirical correction factor can be calculated.

To develop a gas hydrate correction factor for acoustic measurements, it is necessary to calculate an acoustic transit-time relation between a rock saturated with water and a second saturated with gas hydrate in which all other parameters are constant or controlled. In order to determine the acoustic velocity of a rock saturated with gas hydrate, the theoretical velocity constants for ice as determined by Pandit and King (1979) have been used in conjunction with the results of Whiffen and others (1982). W: .4 the aid of Brillouin spectroscopy, Whiffen and others (1982) determined that the acoustic velocity of a gas hydrate (Structure $\mathrm{I}$ ) is approximately 0.88 that of ice. By taking this experimentally derived relation between the acoustic velocity of gas hydrate and ice, along with the work of Pandit and King (1979), it is possible to calculate an acoustic velocity relation between a water-saturated unit and a gas-hydrate saturated unit. Collett and others (1984), calculated a series of acoustic velocities for a rock unit (Boise Sandstone) assumed to be saturated with each of the following pore-filling constituents: gas hydrate(I), ice, and water (table 4). As in the case of the neutron porosity correction factor determined earlier, it is possible to calculate a correction factor for the acoustic transit-time measurements in a gas hydrate. If constant porosity is assumed, the following relation can be written for the acoustic velocity characteristics of Structure I gas hydrate and water within a given pore volume: 


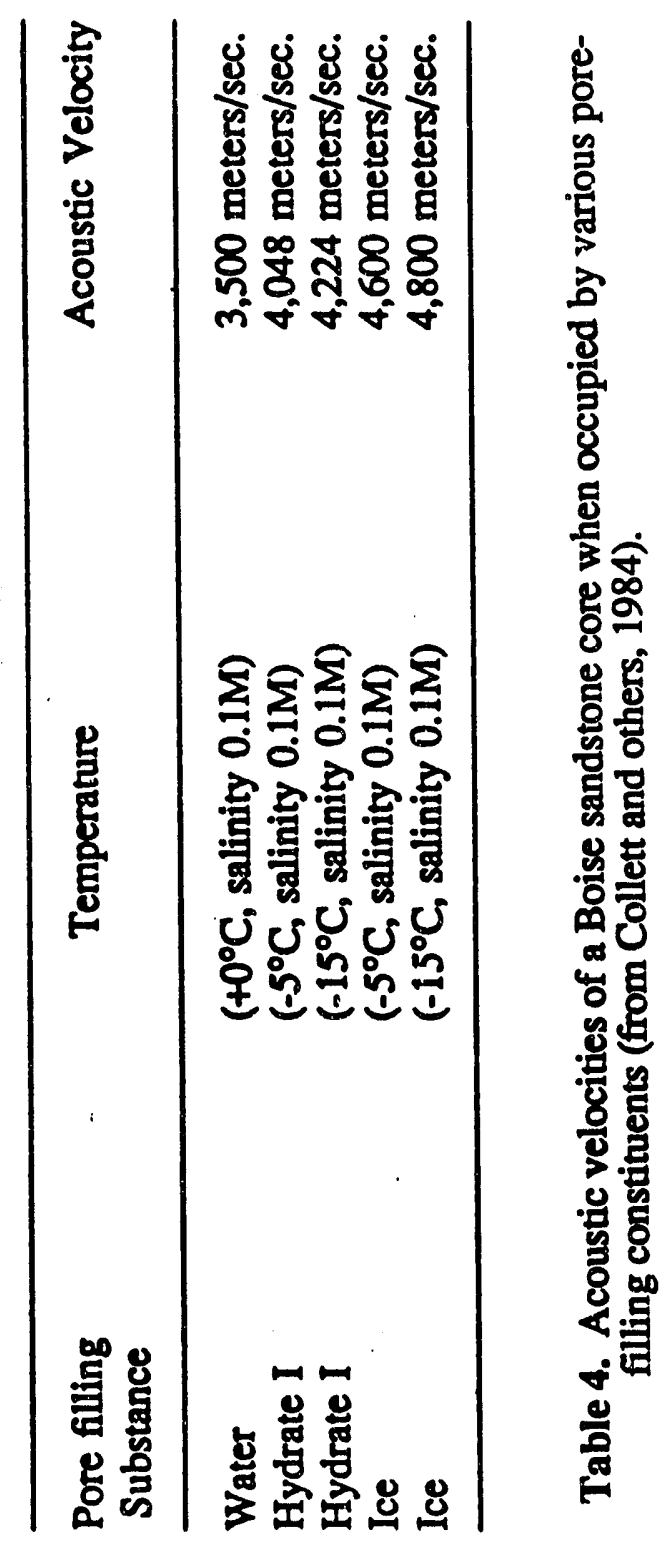


Velocity of Boise Sandstone saturated with gas hydrate (I)

Velocity of Boise Sandstone saturated with water

$$
\frac{4,048 \mathrm{~m} / \mathrm{sec}}{3,500 \mathrm{~m} / \mathrm{sec}}=1.16
$$

To correct porosity calculations made from the acoustic transit-time device in a gas hydrate, the ratio of 1.16 can be utilized as an correction factor. Mathews (1986) used the acoustic transit-time $\log$ to calculate porosities within the gas-hydrate-bearing intervals in the Northwest Eileen State-2 well. Mathews (1986) obtained a gas hydrate acoustic transittime correction factor of 1.49 by comparing the log values of a non-gas-hydrate-bearing interval to the log values in the cored gas hydrate interval.

\section{C. Gas Hydrate Saturation}

Collett and others (1984) assumed that a Pickett crossplot, commonly used to determine oil saturations in oil/water systems, could be used to determine the degree of gashydrate saturation in a-gas-hydrate- and water-bearing rock unit. The accuracy of this procedure is not known. No laboratory or core studies have been conducted to test the usefulness of the Pickett crossplots relative to gas-hydrate research. A Pickett crossplot is based on the following logic: if the pore-space of a rock unit is $100 \%$ saturated with water, the deep resistivity device will record the resistivity of the $100 \%$ water-saturated rock unit $\left(R_{0}\right)$. The water-saturated unit is considered a relative base line from which hydrocarbon saturations can be determined. If the salinity of the pore-fluids is known to be constant within the units being studied, the recorded resistivity measurements can be plotted on a Pickett crossplot, and any deviation from the known $100 \%$ water-saturated resistivity measurement would indicate the presence of hydrocarbons. Similarly, the recorded 
resistivity values for a gas-hydrate saturated unit would vary substantially from the known water-saturated unit, and this difference can be used to calculate gas-hydrate saturation.

A series of Pickett crossplots were used to calculate gas hydrate saturation in four of the six delineated gas-hydrate occurrences overlying the Prudhoe Bay and Kuparuk River oil fields on the North Slope of Alaska (Collett and others, 1988). In the composite Pickett crossplot in figure 8 the corrected neutron-porosity and deep-resistivity log values have been plotted for twenty-seven of the individual gas-hydrate occurrences. In figure 8, the resistivity of the formation waters was determined to be $0.4 \mathrm{ohm}-\mathrm{m}$ (pore-fluid salinity of about 10 to $15 \mathrm{ppt}$ ), and the gas-hydrate saturations range from 70 to 95 percent.

The Pickett crossplot technique is susceptible to erroneous assumptions and interpretations. For example, the incorrect identification of a potential gas-hydrate occurrence or the wrong selection of $a R_{0}$ line can alter the final saturation calculations. In addition, crossplot methods used to determine gas-hydrate saturation can only be used for a gas-hydrate interval below the base of the ice-bearing permafrost. Because of the relatively high resistivity of ice within the permafrost sequence, the comparison of a gas-hydrate saturated unit to an ice-saturated unit will result in an erroneous gas-hydrate saturation value. In using the crossplot-method to determine gas-hydrate saturation, it is assumed that the non-gas-hydrate saturated pore-space within a gas hydrate is occupied by free-water and not ice.

Mathews (1986) also used the Pickett crossplot technique to estimate gas hydrate saturation in the Northwest Eileen State-2 well. In Mathews (1986) the corrected acoustic transit-time data was used as the source of porosity data for the Pickett crossplot. In Collett and others (1983), corrected neutron porosities were used to construct the Pickett crossplots. It appears, however, that both approaches yield similar gas hydrate saturations. Mathews (1986) also estimated the amount of methane gas within the gas hydrate occurrences of the Northwest Eileen State- 2 and Site 570 wells by using a well-log normalization technique. At Site 570 , the resistivity well log plateaus in the massive gas 


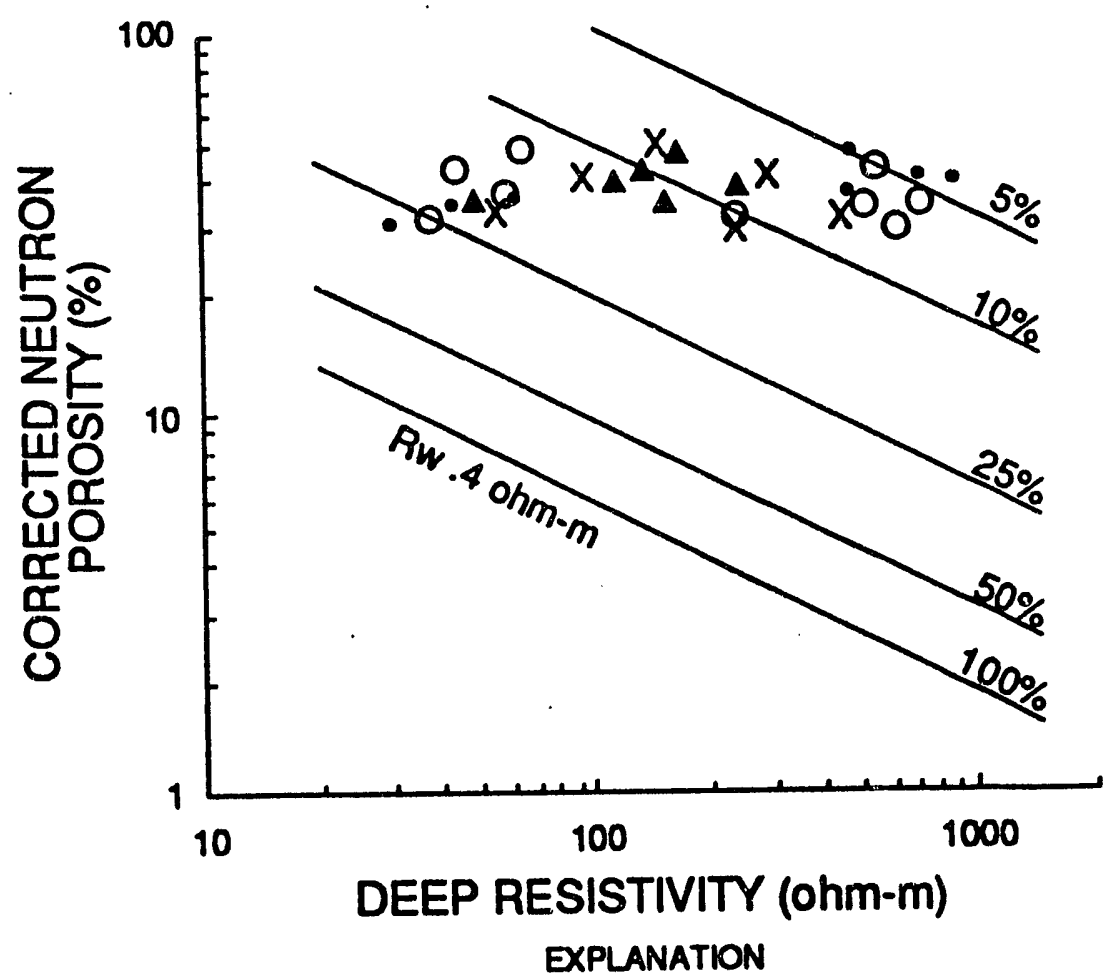

A Unit B - Unit C O Unk D X Unit E Figure 8. Composite Pickett crossplot used to calculate gas-hydrate saturation in four of
the gas-hydrate-bearing rock units overlying the Prudhoe Bay-Kuparuk River area of northern Alaska. 
hydrate zone, indicating a 100\% gas-hydrate saturated interval. Mathews (1986) normalized the resistivity data and assumed that a value of 1.0 indicates a $100 \%$ pure gas hydrate (figure 9). Therefore, any deviation from 1.0 indicates that gas hydrate has been replaced by rock matrix material and formation water. In the Northwest Eileen State-2 well, Mathews (1986) normalized the deep-resistivity log in the cored gas hydrate interval (figure 10). It was assumed that the $2,000 \mathrm{ohm}-\mathrm{m}$ limit indicates a reservoir rock sequence that is $100 \%$ saturated with gas hydrate. The value of 1.0 on the plot in figure 10 represents $100 \%$ gas hydrate saturation. As in the Site 570 well, any deviation from 1.0 indicates that the gas hydrate has been replaced by rock material and formation water. Mathews (1986) used his calculated gas hydrate saturations, derived from the normalization technique and the Pickett crossplot, to estimate the amount of methane gas in the cored gas hydrate interval of the Northwest Eileen State-2 well. Mathews (1986) normalized resistivity technique yielded an estimate of $412.4 \times 10^{6} \mathrm{~m}^{3}$ of gas per square kilometer and the Pickett crossplot technique yielded as estimate of $191.6 \times 10^{6} \mathrm{~m}^{3}$ of gas per square kilometer. 


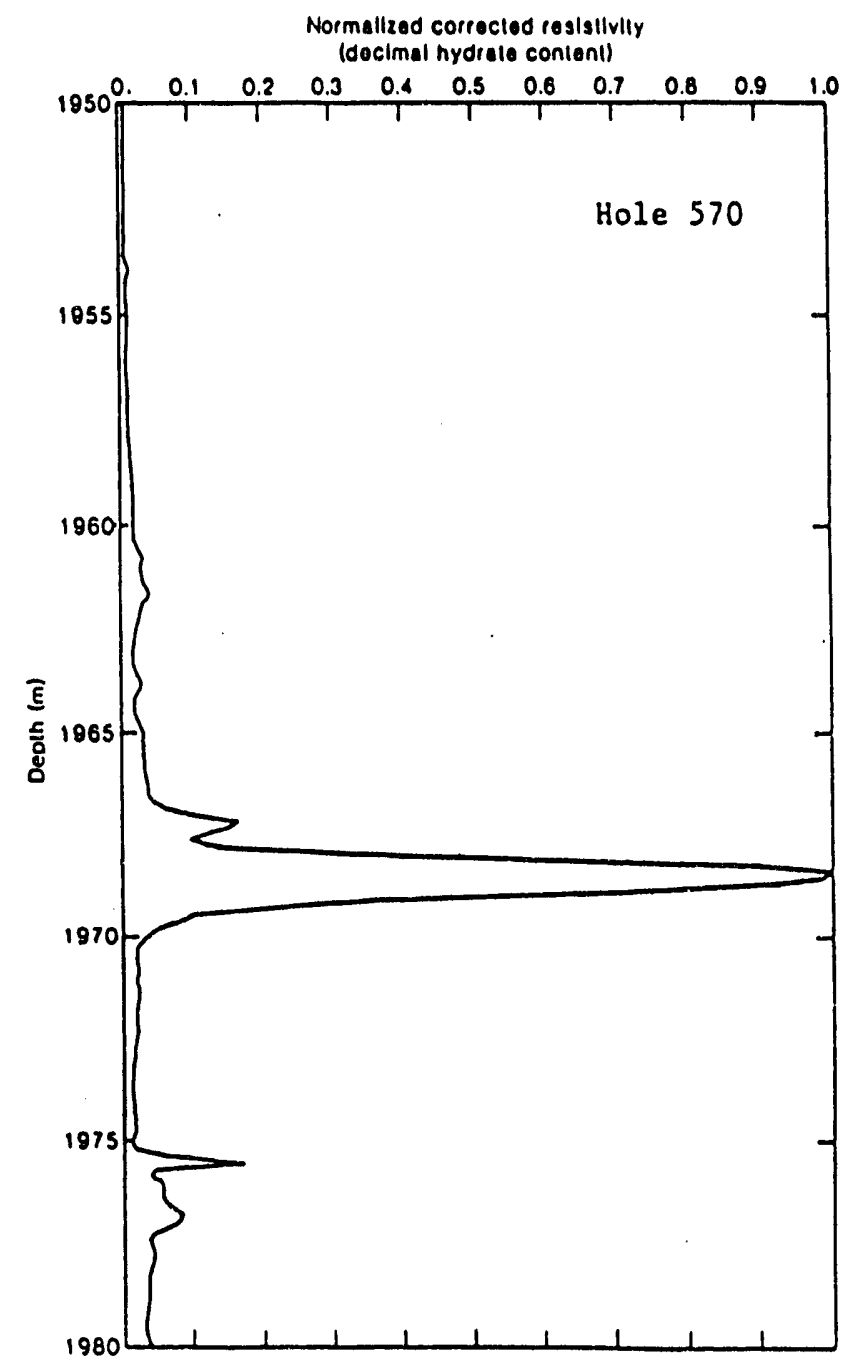

Figure 9. Normalized resistivity data (clld) from the cored gas hydrate interval in the DSDP Site 570 well (from Mathews, 1986). 


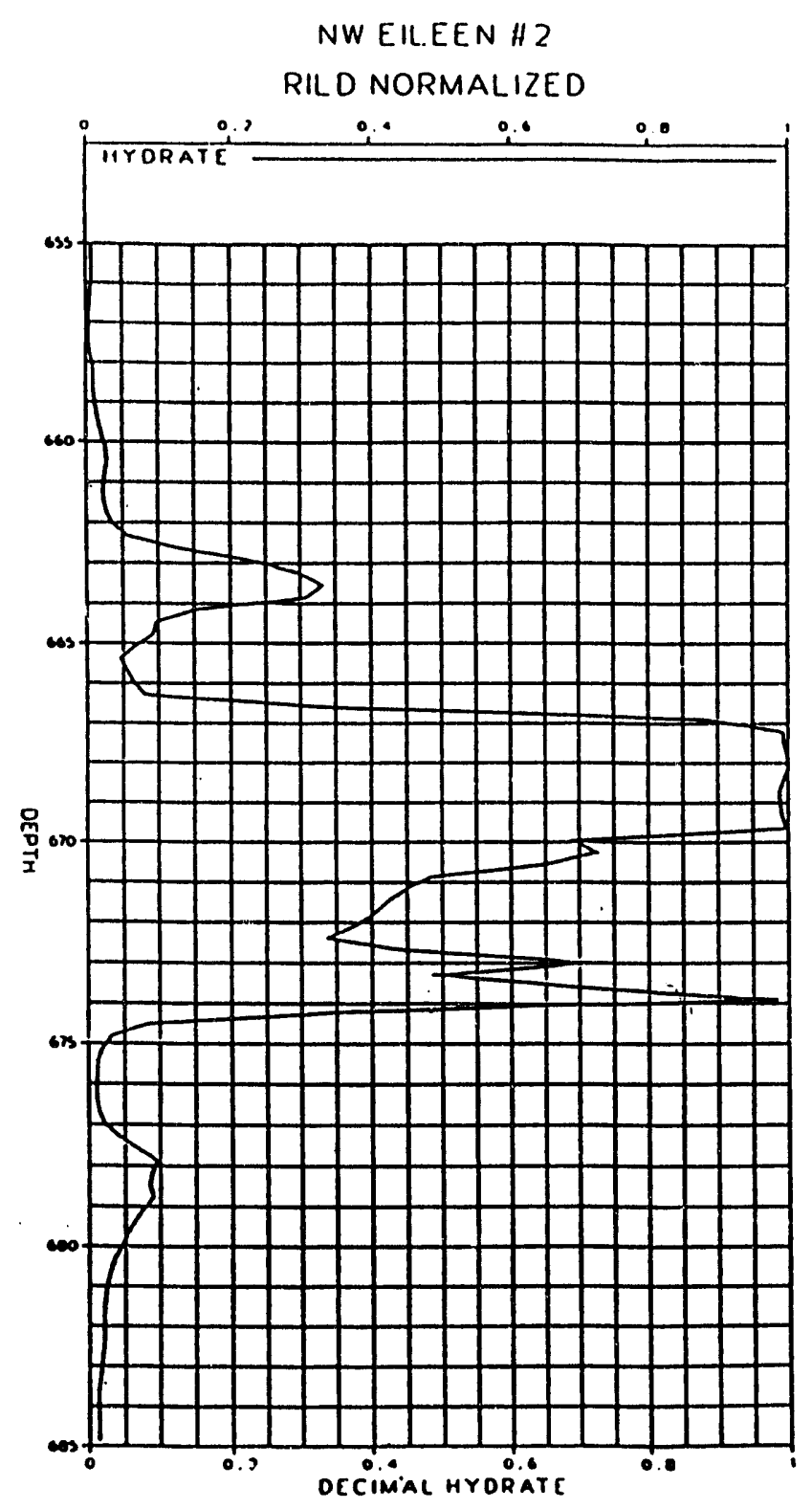

Figure 10. Normalized resistivity data (RILD) from the cored gas hydrate interval in the Northwest Eileen State-2 well (from Mathews, 1986). 


\section{CONCLUSION}

As interest in gas hydrates continues to grow the need to answer the question what is the volume of gas hydrates and included natural gas within a gas hydrate occurrence will become more pressing. Most of the existing gas hydrate log evaluation techniques are qualitative in nature and have been developed by the extrapolation of standard oil industry procedures. Relatively little work has been done to check the usefulness of these standard $\log$ evaluation techniques in a gas hydrate system. Most certainly more work is required to characterize the nature of well log responses to the presence of gas hydrates. 


\section{REFERENCES CITED}

Arctic Slope Consulting Group, 1990, A review of the geoscience evaluation of the Walakpa gas accumulation: Review conducted by North Slope Borough Science Advisory Committee, North Slope Borough, Barrow, Alaska, 65 p.

Bily, C., and Dick, J.W.L., 1974, Natural occurring gas hydrates in the Mackenzie Delta, Northwest Territories: Bulletin of Canadian Petroleum Geology, v. 22, no. 3, p. 340-352.

Brooks, J.M., Cox , H.B., Bryant, W.R., Kennicutt, M.C., Mann, R.G., and McDonald, T.J., 1986, Association of gas hydrates and oil seepage in the Gulf of Mexico, in Advances in Organic Geochemistry 1985: Organic Geochemistry, v. 10, p. 221234.

Carman, G.J., and Hardwick, Peter, 1983, Geology and regional setting of the Kuparuk oil field, Alaska: American Association of Petroleum Geologists Bulletin, v. 67, no. 6, p. 1014-1031.

Cherskiy, N.V., Tsarev, V.P., and Nikitin, S.P., 1985, Investigation and prediction of conditions of accumulation of gas resources in gas-hydrate pools: Petroleum Geology, v. 21, p. 65-89.

Collett, T.S., 1983, Detection and evaluation of natural gas hydrates from well logs, Prudhoe Bay, Alaska, Proceedings of the Fourth International Conference on Permafrost, Fairbanks, Alaska: National Academy of Sciences, Washington D.C., p. 169-174.

Collett, T.S., 1990, Potential geologic hazards of Arctic gas hydrates: American Association of Petroleum Geologists Bulletin v. 74, no. 5, p. 631-632.

Collett, T.S., Bird, K.J., Kvenvolden, K.A., and Magoon, L.B., 1988, Geologic interrelations relative to gas hydrates within the North Slope of Alaska: U.S. Geological Survey Open-File Report 88-389, 150 p.

Collett, T.S., Godbole, S.P., and Economides, C.E., 1984, Quantification of in-situ gas hydrates with well logs: Proceedings of the 35th Annual Technical Meeting of the Petroleum Society of CIM, Calgary, Canada, June 10-13, p. 571-582.

Collett, T.S., Kvenvolden, K.A., and Magoon, L.B., 1989, Characterization of hydrocarbon gas within the stratigraphic interval of gas-hydrate stability on the North Slope of Alaska: Applied Geochemistry, v. 5, p. 279-287.

Davidson, D.W., and Ripmeester, J.A., 1984, NMR, NQR and dielectric properties of clathrates: in Atwood, J.L., Davies, J.E.D., and MacNichol, D.D., eds., Inclusion Compounds, v. 3, chapter 3, p. 69-127.

Franklin, L.J., 1980, In-situ hydrates-a potential gas source: Petroleum Engineer International, November, p. 112-122.

Gryc, George, 1988, Geology and exploration of the Natural Petroleum Reserves in Alaska, 1974 to 1982: U.S. Geological Survey Professional Paper 1399, 940 p. 
Harrison, W.E., and Curiale, J.A., 1982, Gas hydrates in sediments of Holes 497 and 498A, Deep Sea Drilling Project Leg 67, in Aubouin, J., Von Huene, R., and others, eds., Initial Report Deep Sea Drilling Project, v. 67: U.S. Government Printing Office, Washington, D.C., p. 591-594.

Hearst, J.R., and Nelson, P.H., 1985, Well logging for physical properties: McGraw-Hill Book Company, New York, 571 p.

Hitchon, B., 1974, Occurrence of natural gas hydrates in sedimentary basins, in Kaplan, I.R., ed., Natural Gases in Marine Sediments: Plenum Publishing, New York, p. 195-225.

Hunt, J.M., 1979, Petroleum geology and geochemistry: W.H. Freeman and Company, San Francisco, California, 716 p.

Judge, A.S., 1988, Mapping the distribution and properties of natural gas hydrates in Canada: Proceedings of the American Chemical Society Third Chemical Congress of the North American Continent, June 6-7, Toronto, Ontario, Abstract Number 29.

Kvenvolden, K.A., 1988, Methane hydrate-a major reservoir of carbon in the shallow geosphere?: Chemical Geology, v. 71, p. 41-51.

Kvenvolden, K.A., and Barnard, L.A., 1983, Gas hydrates of the Blake Outer Ridge, Site 533, Deep Sea Drilling Project Leg 76, in Sheridan, R.E., Gradstein, F., and others, eds., Initial Report Deep Sea Drilling Project, v. 76: U.S. Government Printing Office, Washington, D.C., p. 353-365.

Kvenvolden, K.A., and Kastner, M., 1989, Gas hydrates of the Peruvian continental margin, in Suess, E., Von Huene, R., Emeis, K.C., and others, eds., Initial Report Ocean Drilling Program, v. 112 (Part B): U.S. Government Printing Office, Washington, D.C., p. (in press).

Kvenvolden, K.A., and MacDonald, T.J., 1985, Gas hydrates of the Middle America Trench, Deep Sea Drilling Project Leg 84, in Von Huene, R., Aubouin, J., and others, eds., Initial Report Deep Sea Drilling Project, v. 84: U.S. Government Printing Office, Washington, D.C., p. 667-682.

Kvenvolden, K.A., and McMenamin, M.A., 1980, Hydrates of natural gas: a review of their geologic occurrences: U.S. Geological Survey Circular 825, 11 p.

MacDonald, G.J., 1983, The many origins of natural gas: Journal of Petroleum Geology, v. 5 , p. $341-362$.

Makogon, Y.F., 1981, Hydrates of natural gas: Tulsa, Penn Well Publishing Company, $237 \mathrm{p}$.

Makogon, Y.F., 1988, Natural gas hydrates--the state of study in the USSR and perspectives for its use: paper presented at the Third Chemical Congress of North America, Toronto, Canada, June 5-10, 18 p. 
Makogon, Y.F., Trebin, F.A., Trofimuk, A.A., Tsarev, V.P., and Cherskiy, N.V., 1972, Detection of a pool of natural gas in a solid (hydrate gas) state: Doklady Academy of Sciences U.S.S.R., Earth Science Section, v. 196, p. 197-200.

Mathews, Mark, 1986, Logging characteristics of methane hydrate: The Log Analyst, v. 27 , n. 3 , p. $26-63$.

Pandit, B.I., and King, M.S., 1979, A study of the effects of pore-water salinity on some physical properties of sedimentary rocks at permafrost temperature: Canadian Journal of Earth Sciences, v. 16, p. 1566-1580.

Pandit, B.I., and King, M.S., 1982, Proceedings of the Fourth Canadian Permafrost Conference: Ottawa, National Research Council of Canada, p. 335

Potential Gas Committee, 1981, Potential supply of natural gas in the United States (as of December 31, 1980): Potential Gas Agency, Colorado Schocl of Mines, Golden, Colorado, 199 p.

Schlumberger Educational Services, 1989, Log interpretation principles/applications: Schlumberger Educational Services, Houston, Texas, p. 8-20.

Shipley, T.H., and Didyk, B.M., 1982, Occurrence of methane hydrates offshore southern Mexico, in Watkins, J.S., Moore, J.C., and others, eds., Initial Report Deep Sea Drilling Project, v. 66: U.S. Government Printing Office, Washington, D.C., p. 547-555.

Sloan, E.D., 1990, Clathrate hydrates of natural gases: Marcel Dekker, Inc., New York, New York, 641 p.

Whally, E., 1980, Speed of longitudinal sound in clathrate hydrates: Journal of Geophysical Research, v. 85, n. B5, p. 2539-1542.

Whiffen, B.L., Kiefte, H., and Clouter, M.J., 1982, Determination of acoustic velocities in xenon and methane hydrates by brillouin spectroscopy: Geophysical Research Letters, v. 9, n. 6, p. 645-648.

Yefremova, A.G., and Zhizhchenko, B.P., 1975, Occurrence of crystal hyw-ates of gas in sediments of modern marine basins: Doklady Academy of Sciences U.S.S.R., Earth Science Section, v. 214, p. 219-220.

Yousif, M.H., Abass, H.H., Selim, M.S., and Sloan, E.D., 1983, Experimental and theoretical investigation of methane gas hydrate dissociation in porous media: Proceedings of the 63rd Annual Technical Confe ence and Exhibition of the Society of Petroleum Engineers, October 2-5, Houston, Texas, p. 571-583. 

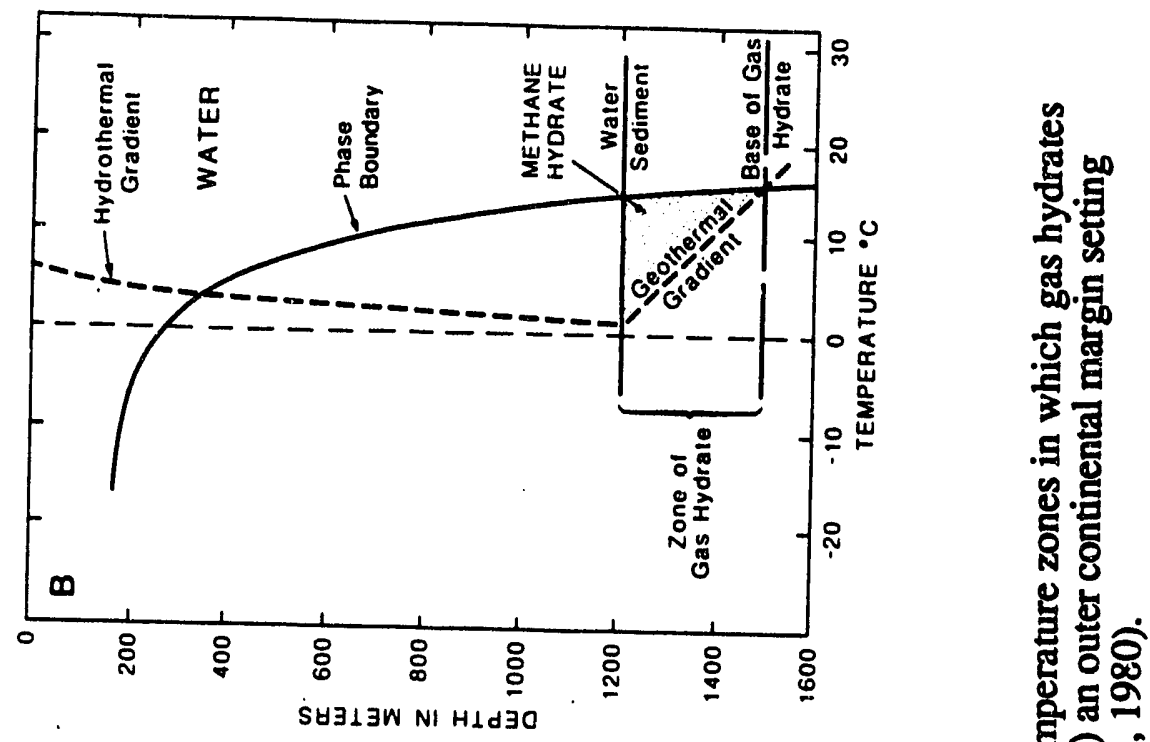

ह

흘

웅

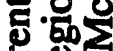

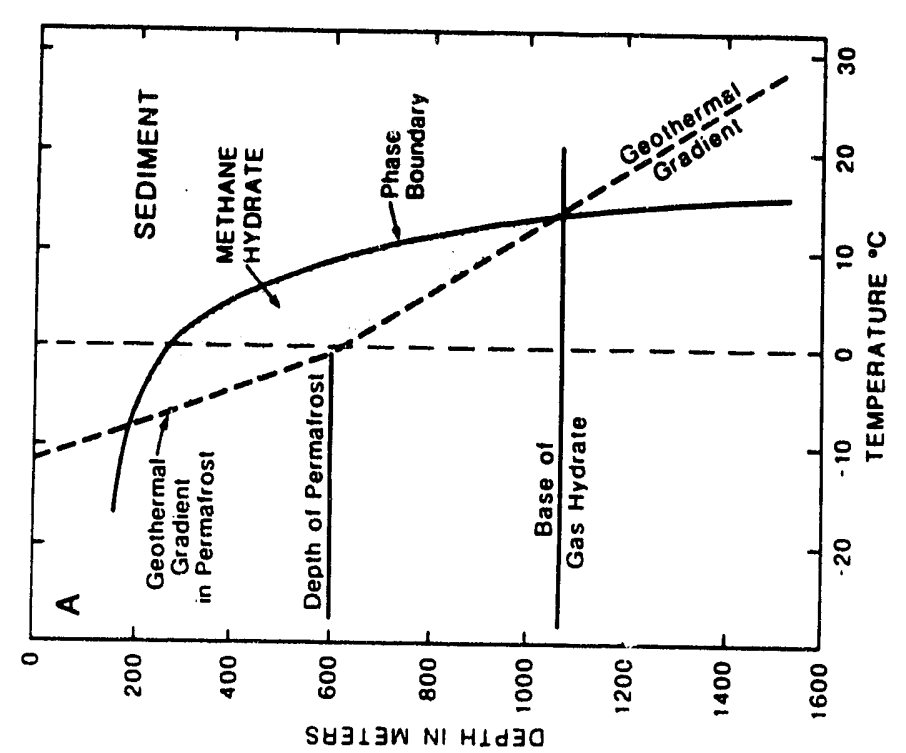

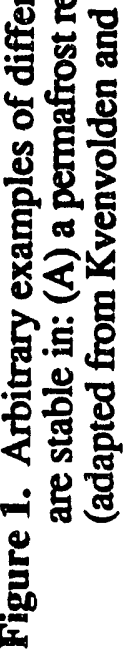




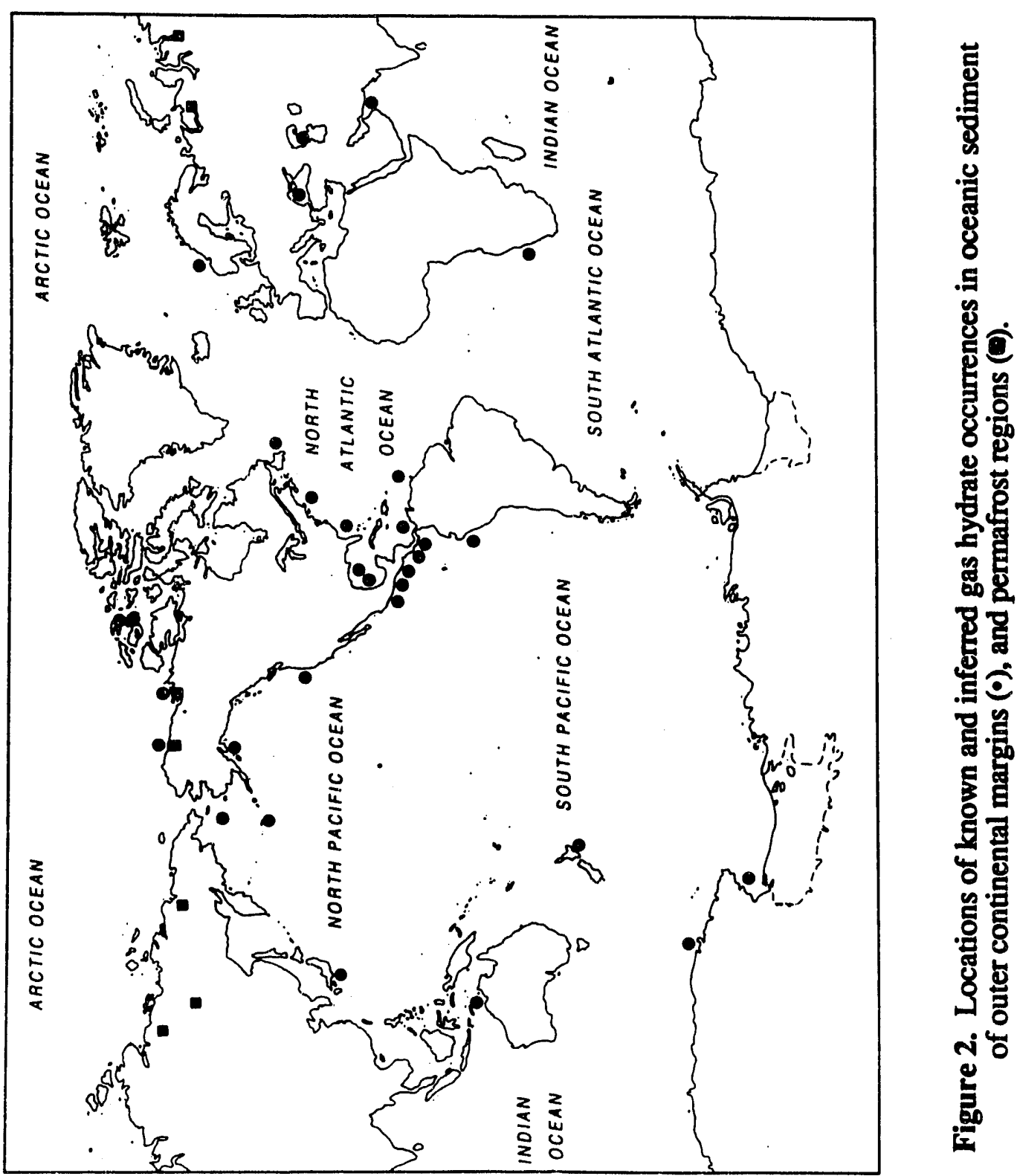




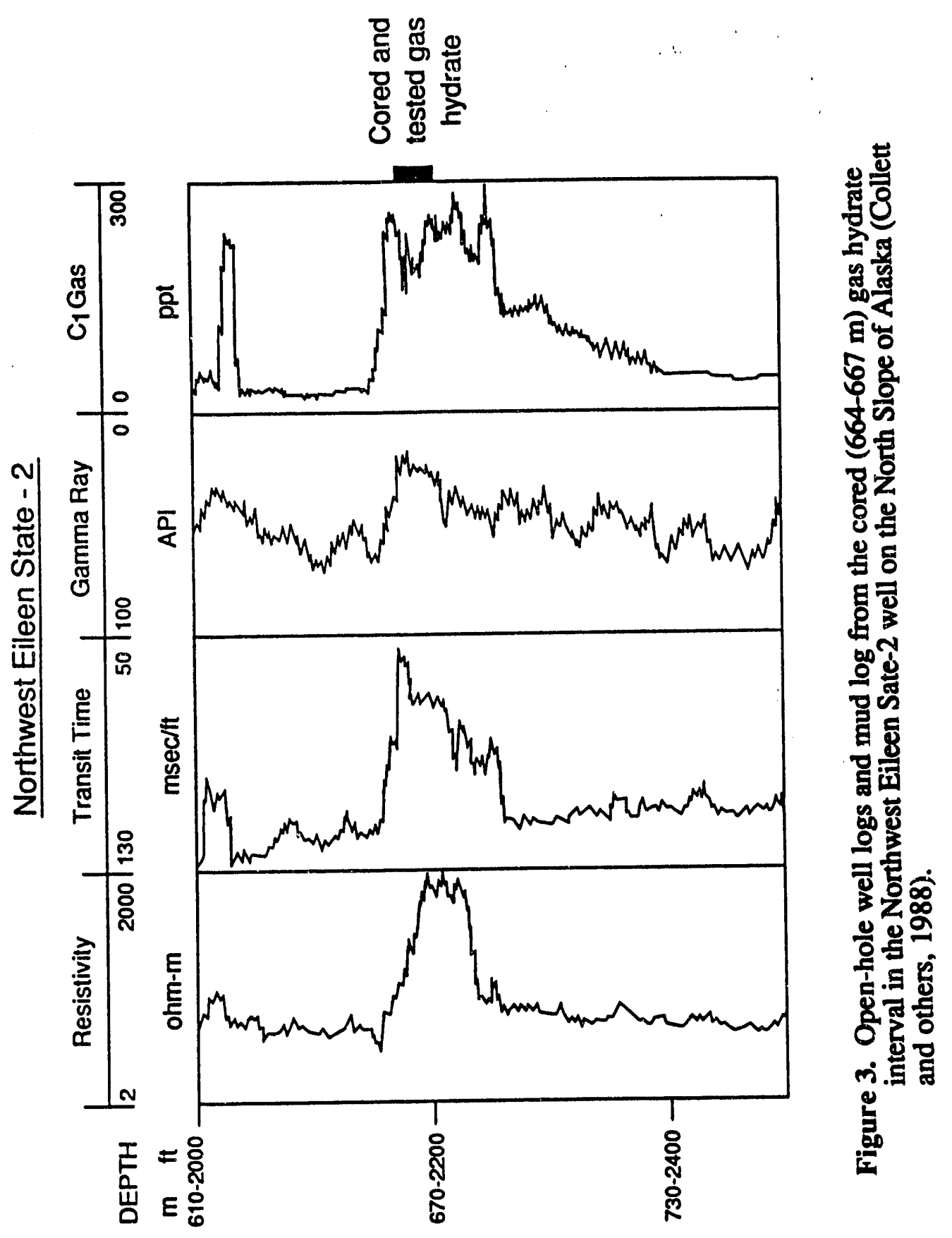




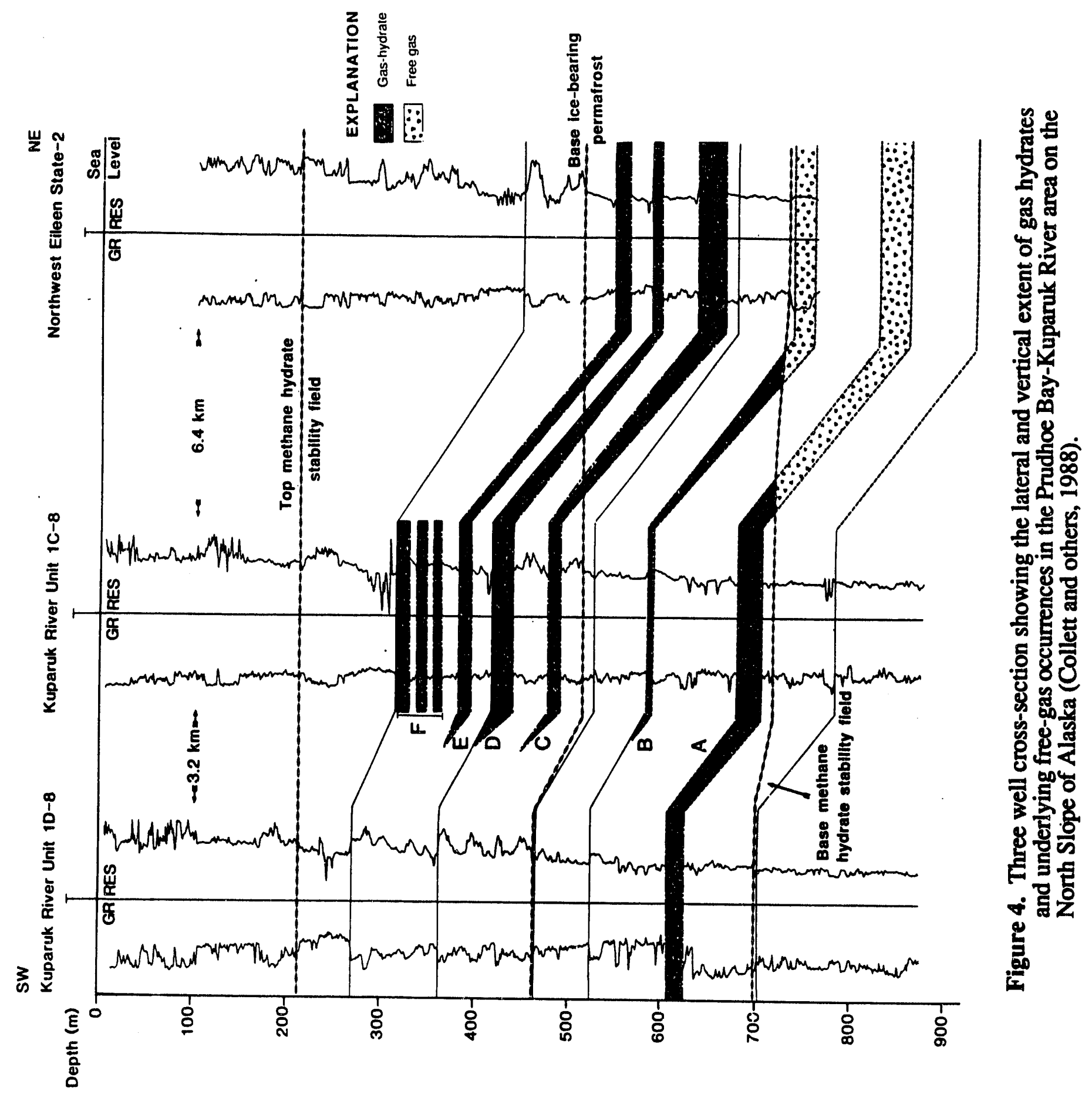




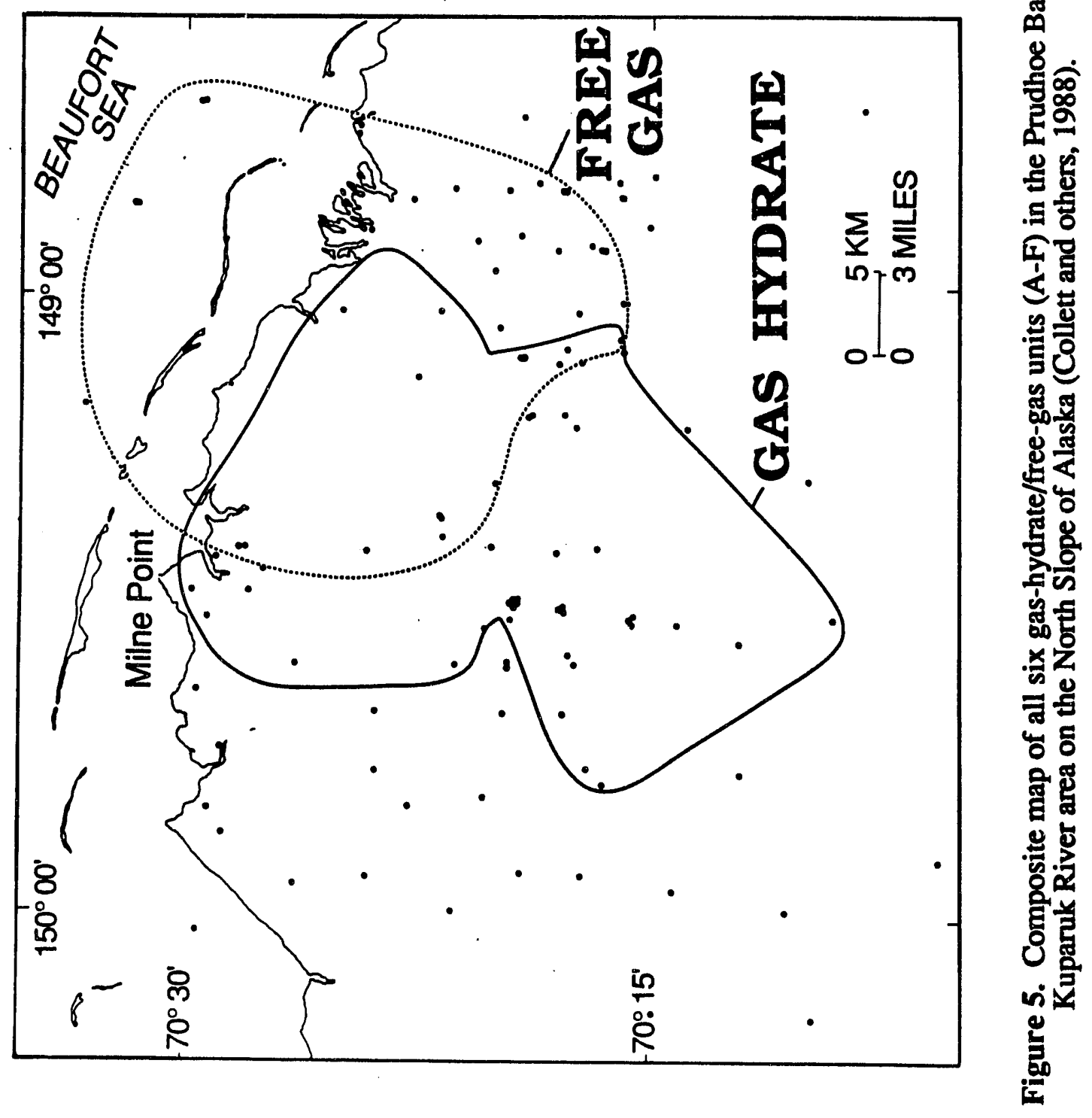




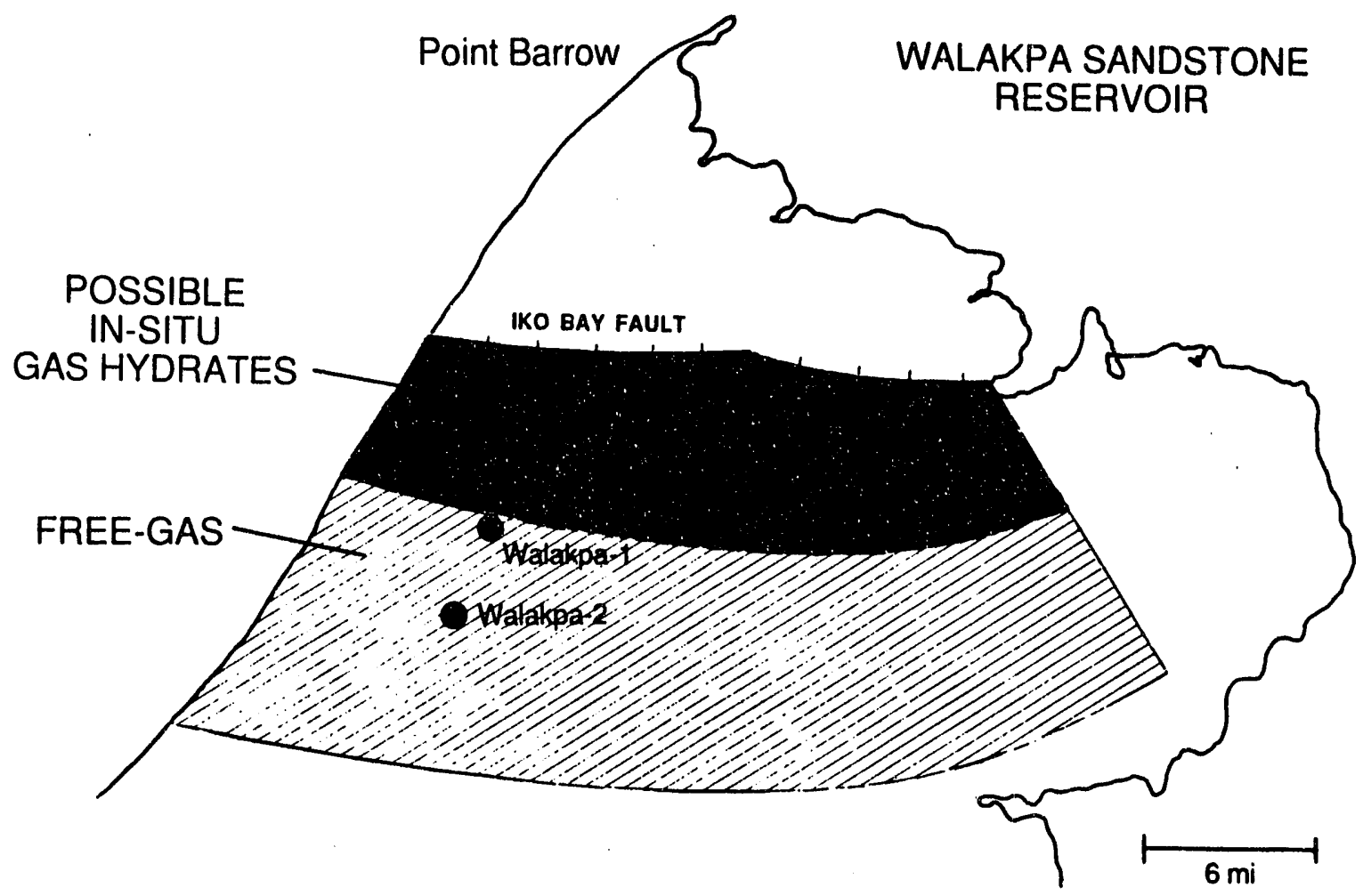

Figure 6. Potential distribution of the gas hydrate stability field in the Walakpa Gas Field on the North Slope of Alaska (Arctic Slope Consulting Group, 1990). 


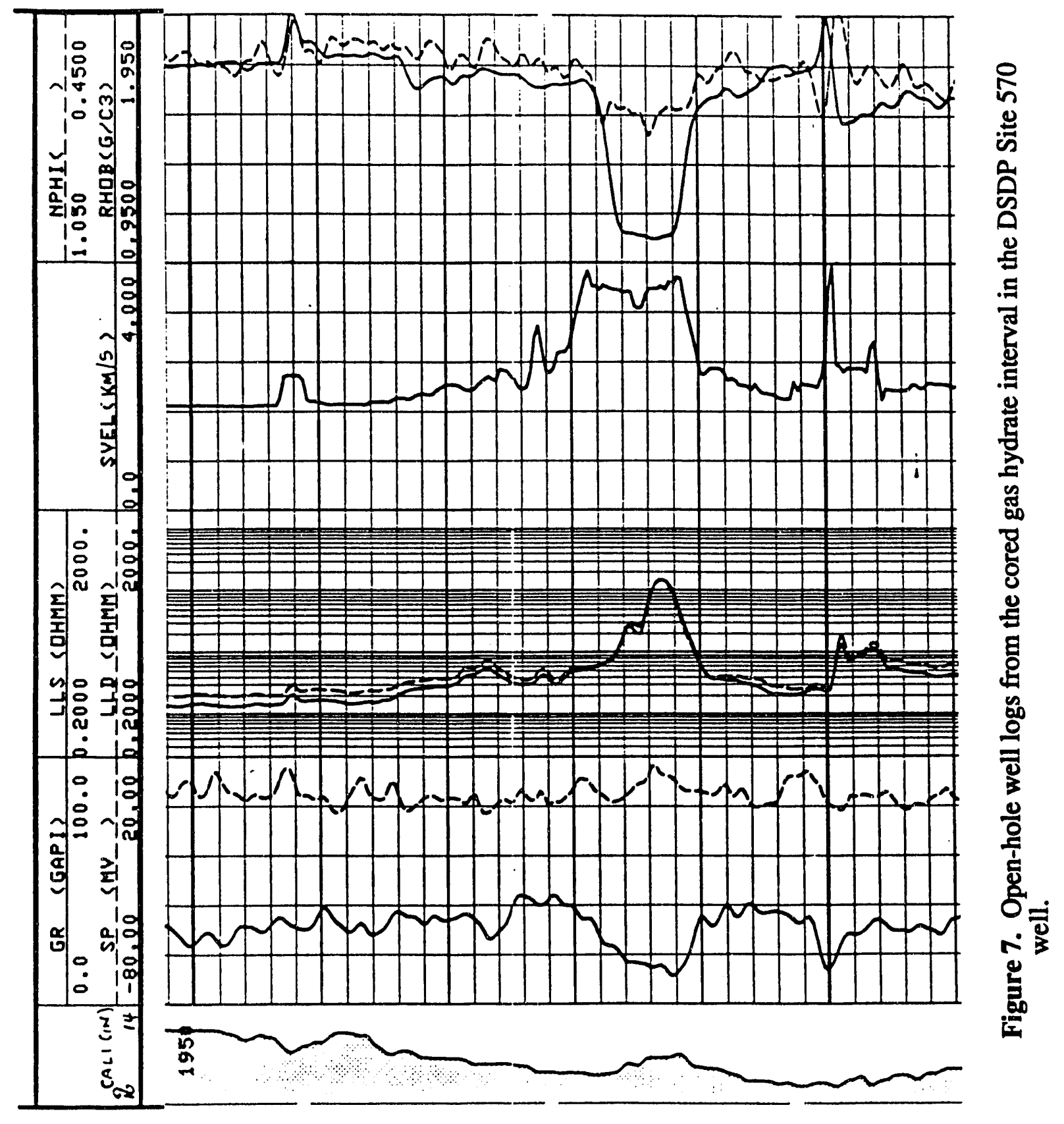




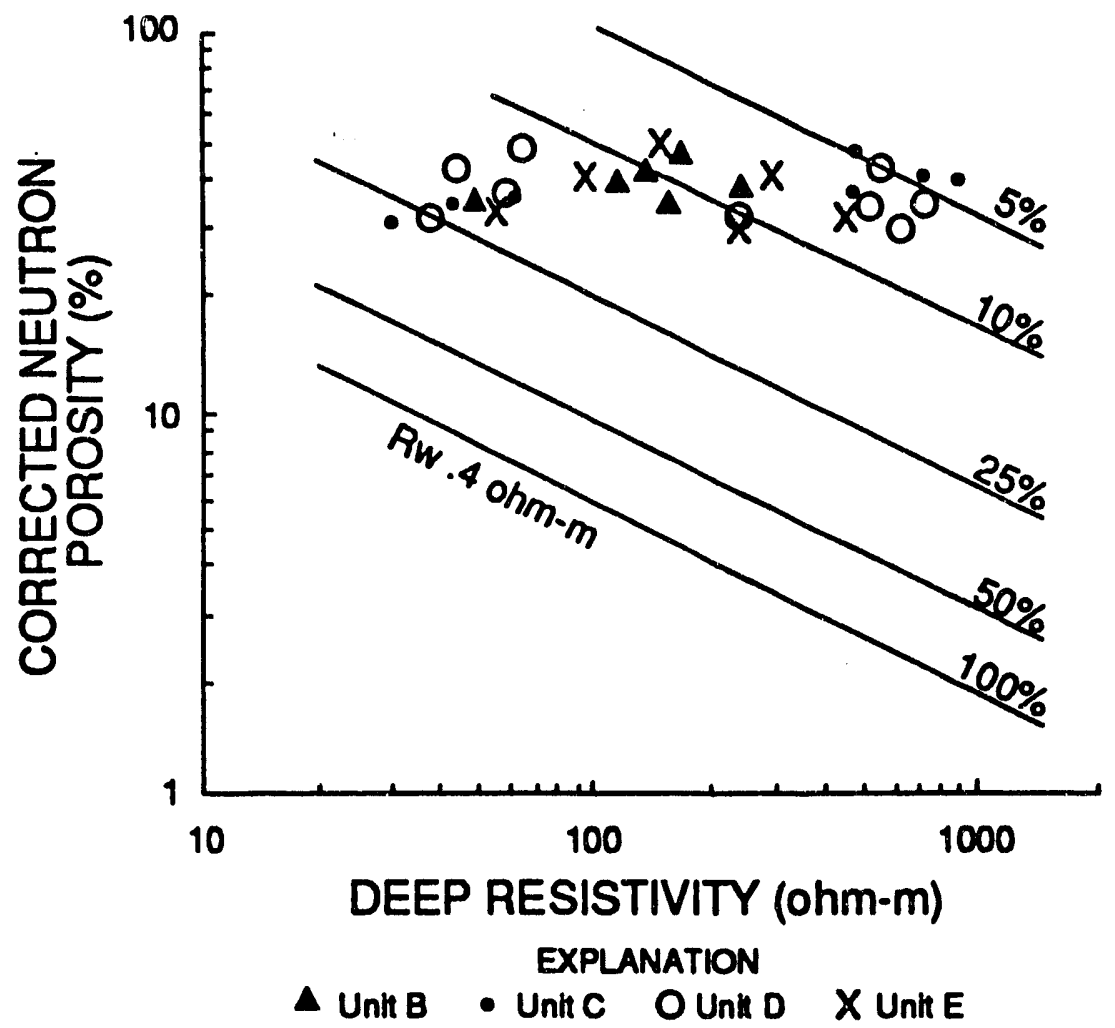

Figure 8. Composite Pickett crossplot used to calculate gas-hydrate saturation in four of the gas-hydrate-bearing rock units overlying the Prudhoe Bay-Kuparuk River area of northern Alaska. 


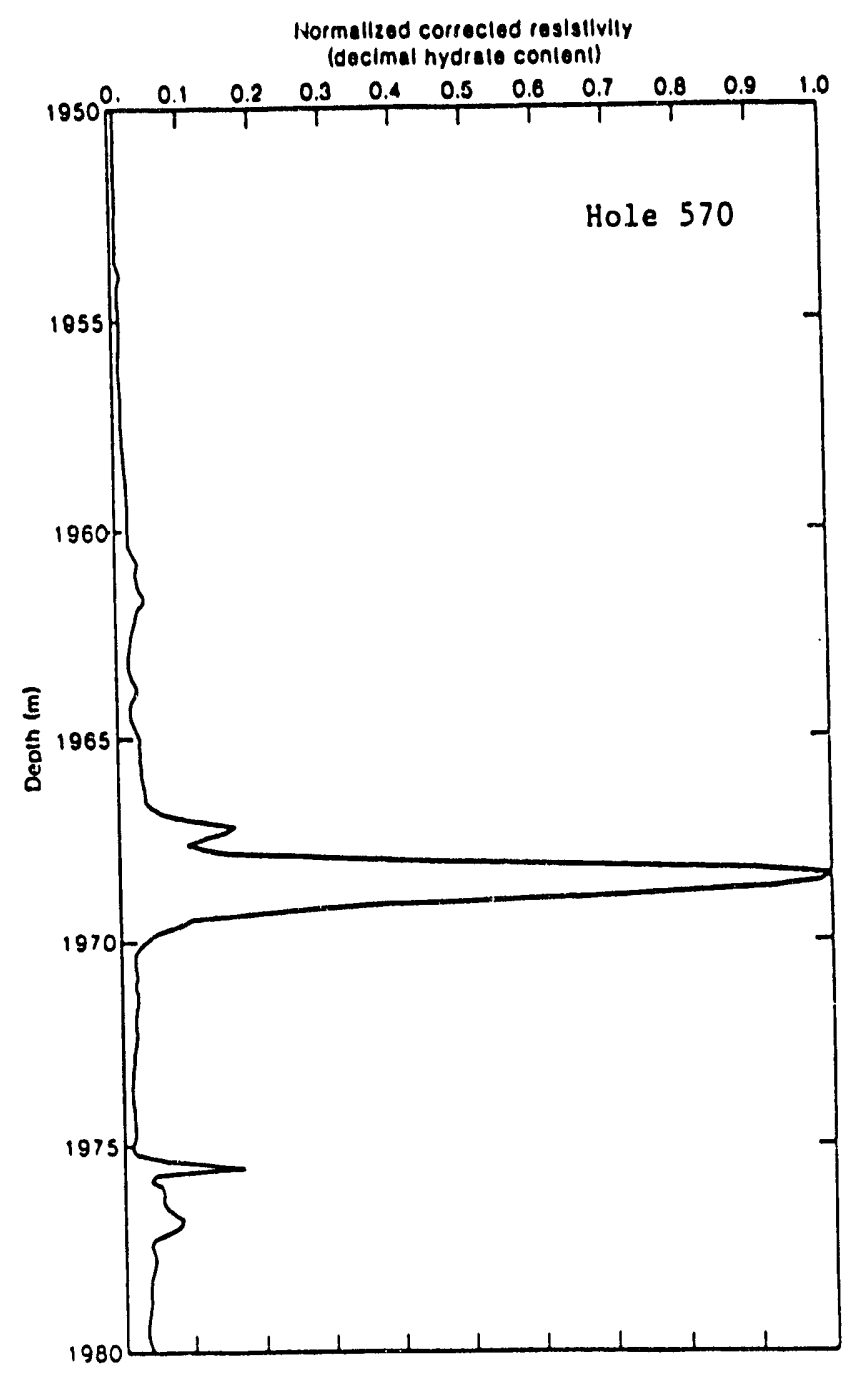

Figure 9. Normalized resistivity data (clld) from the cored gas hydrate interval in the DSDP Site 570 well (from Mathews, 1986). 


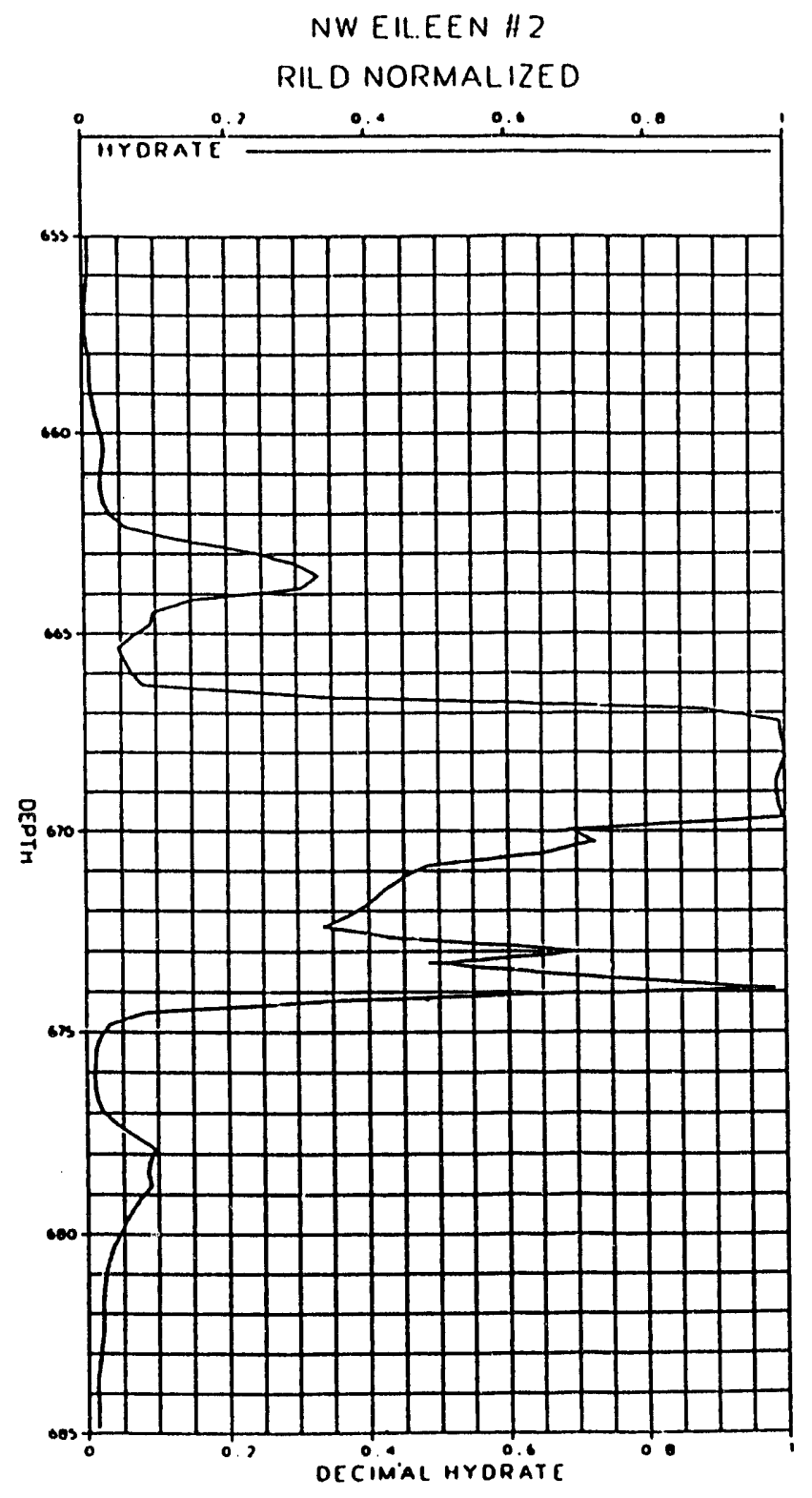

Figure 10. Normalized resistivity data (RILD) from the cored gas hydrate interval in the Northwest Eileen State-2 well (from Mathews, 1986). 
GAS HYDRATES OF DSDP LEG 84 SITE 570

\begin{tabular}{ccl}
$\begin{array}{c}\text { Site \& } \\
\text { Core Number }\end{array}$ & $\begin{array}{c}\text { Subbottom } \\
\text { Depth }(\mathrm{m})\end{array}$ & \multicolumn{1}{c}{ Description } \\
\hline $570-21-1$ & 192 & Ash lamina with hydrate at top of core \\
$570-26-5$ & 246 & Hydrate in fractures of mudstone \\
$570-27-1$ & 249 & Massive hydrate, 1.05 m \\
$570-28$ & $259-268$ & Hydrate in fractures of mudstone \\
$570-29-3$ & 273 & Hydrate in fractures of mudstone \\
$570-32-4$ & 303 & Hydrate with volcanic ash \\
$570-36-1$ & 338 & Hydrate with sand lens \\
\hline
\end{tabular}

Table 1. Description of the gas hydrate occurrences in the DSDP Leg 84 Site 570 well (Kvenvolden and MacDonald, 1985). 
DSDP SITE 570 WELL LOG DEFINED MASSIVE GAS HYDRATE

\begin{tabular}{ll}
\hline \multicolumn{1}{c}{ Log Data } & \multicolumn{1}{c}{$\begin{array}{c}\text { Massive Gas-Hydrate Zone } \\
1,965.4-1,969.4(\mathrm{~m})\end{array}$} \\
\hline P-wave sonic & Defines zone, $4 \mathrm{~m}$ thick \\
Density & Defines zone, $2.7 \mathrm{~m}$ thick \\
Resistivity & Both lls and lld define zone, $0.6 \mathrm{~m}$ deeper \\
Full-wave sonic & Wiggle trace marginally defines zone, \\
& Variable density marginally defines zone \\
Gamma-ray & Defines zone, $0.5 \mathrm{~m}$ deeper \\
Neutron porosity & Defines zone, $0.5 \mathrm{~m}$ deeper \\
SP & Doesn't define zone \\
Caliper & Doesn't define zone \\
Temperature & Doesn't define zone \\
\hline
\end{tabular}

Table 2. Gas hydrate well log response in the DSDP Leg 84 Site 570 well (from Mathews, 1986). 


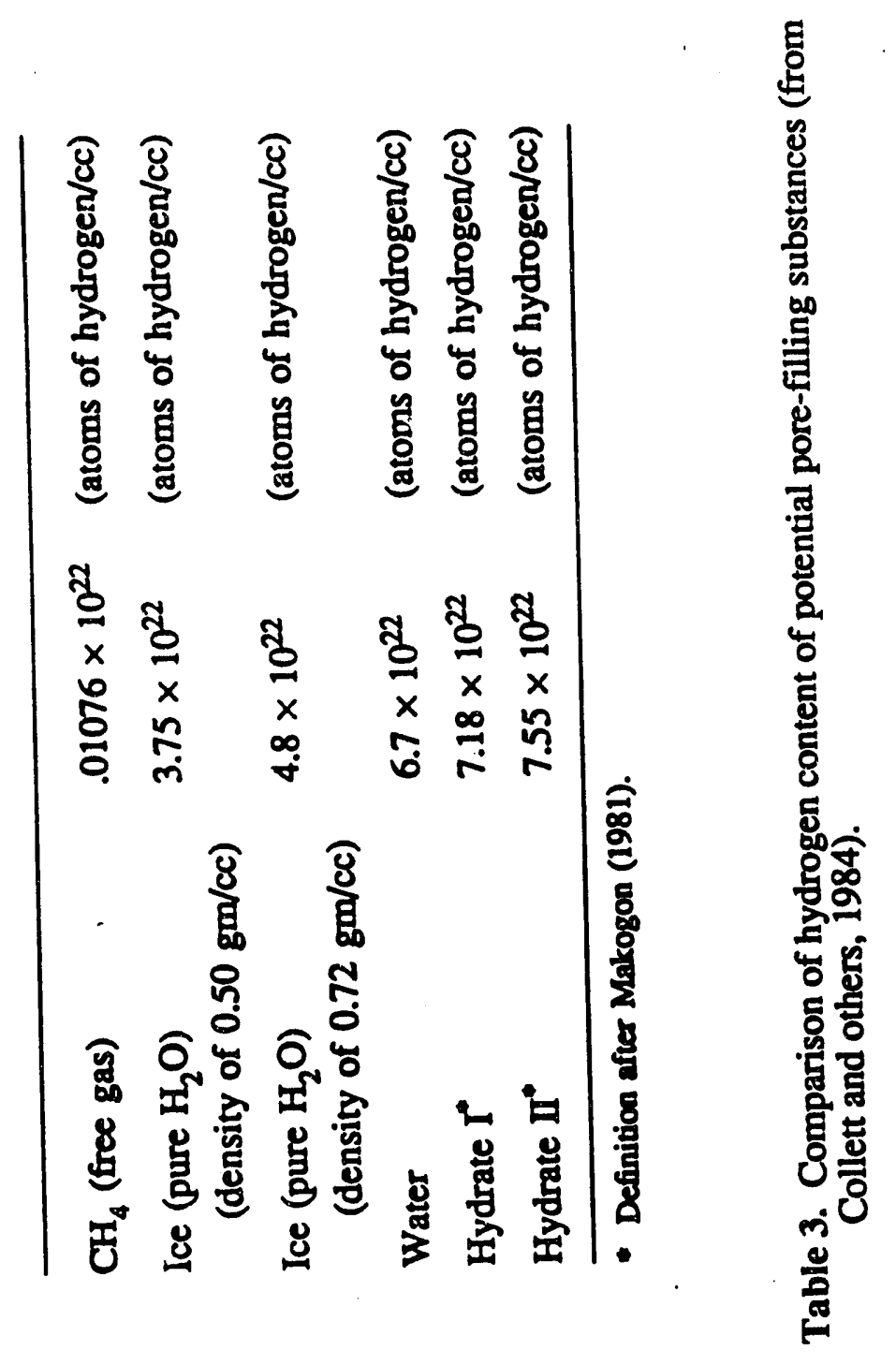




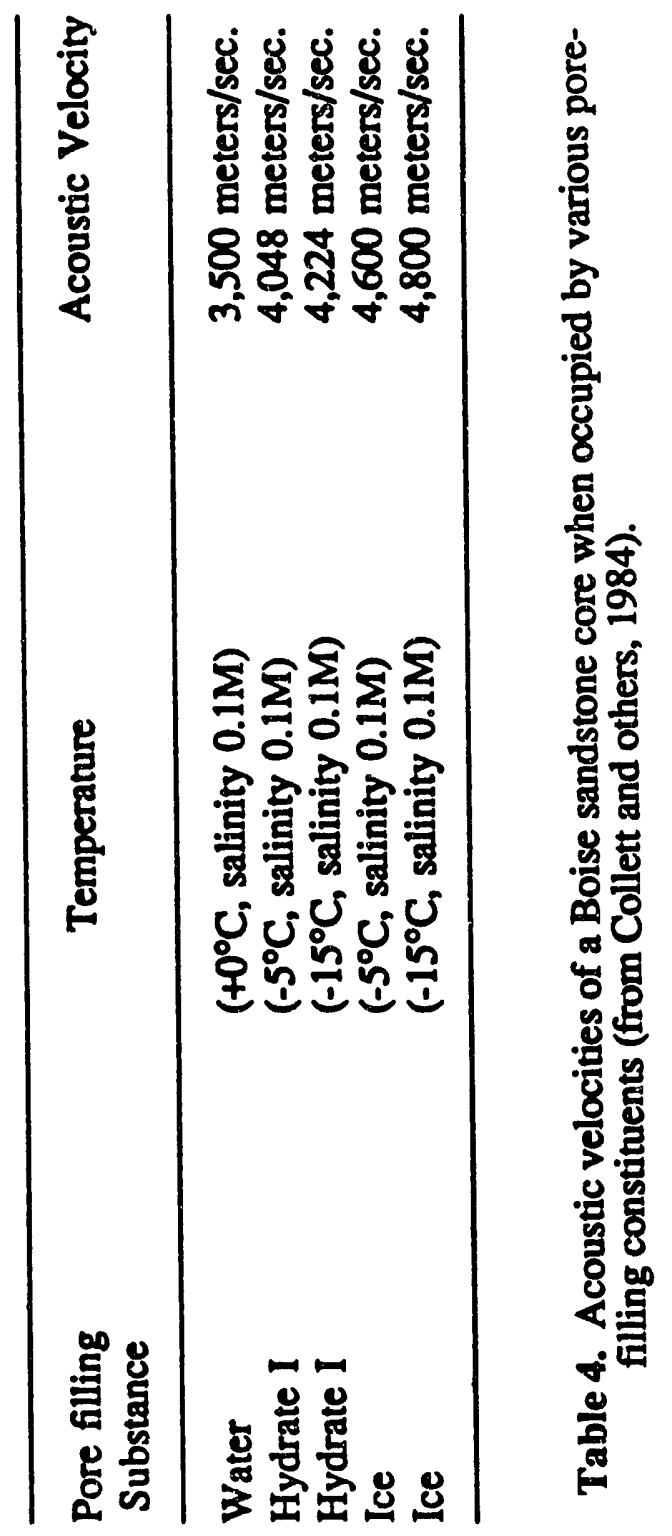



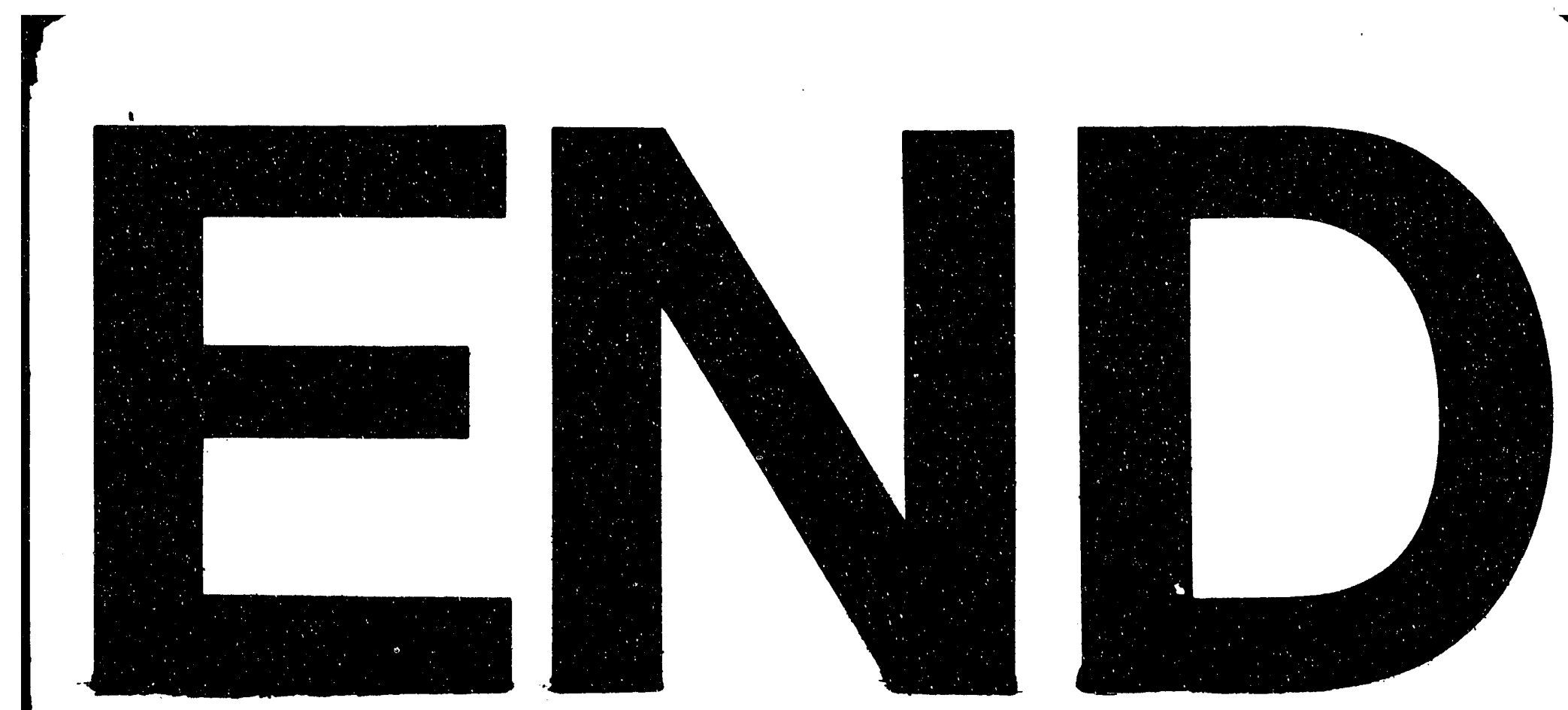

중
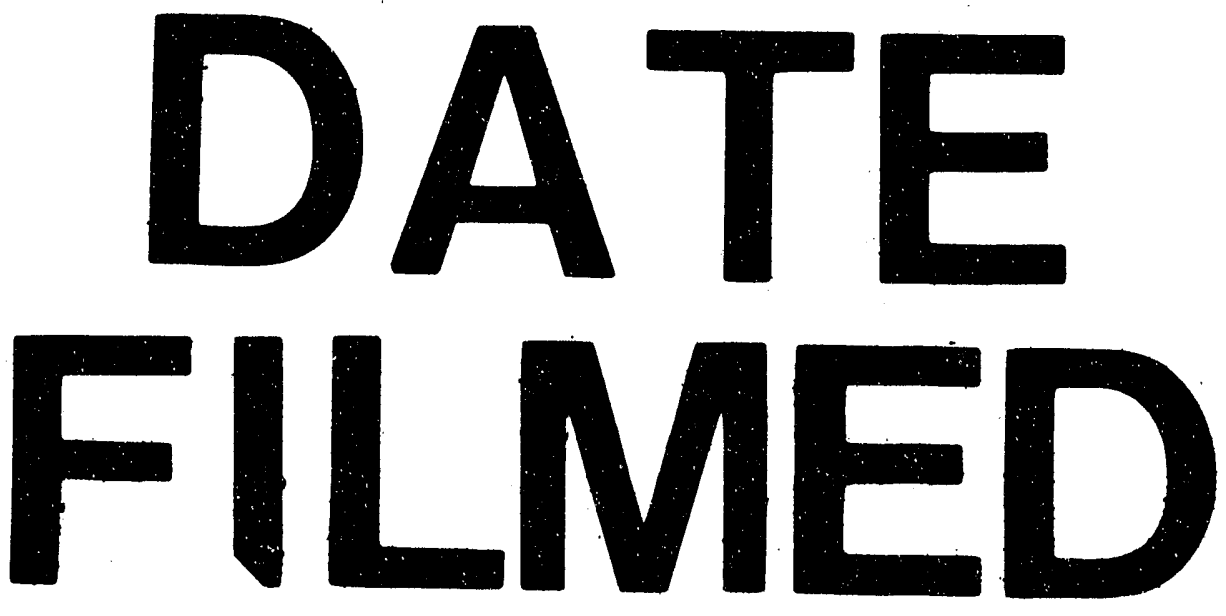

$6.29 / 93$ 


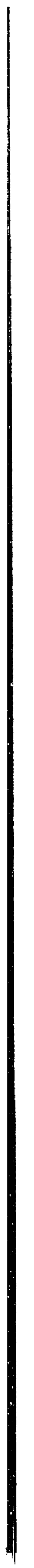

